\title{
Sensitivity of leukemic T-cell lines to arsenic trioxide cytotoxicity is dependent on the induction of phosphatase B220/CD45R expression at the cell surface
}

Mohcine Benbijja ${ }^{1,2}$, Amine Mellouk ${ }^{3}$ and Pierre Bobé ${ }^{1,3^{*}}$

\begin{abstract}
Background: Arsenic trioxide $\left(\mathrm{As}_{2} \mathrm{O}_{3}\right)$ is highly effective in treating acute promyelocytic leukemia (APL), but shows more variable therapeutic efficacy for other types of hematological malignancies. Previously, we reported that $\mathrm{As}_{2} \mathrm{O}_{3}$ selectively eliminates pathogenic B220-expressing T cells in autoimmune MRL/Ipr mice. We investigated herein the relationship between $\mathrm{As}_{2} \mathrm{O}_{3}$ sensitivity of leukemic T-cell lines and the expression levels of the B220 isoform of transmembrane tyrosine phosphatase CD45.
\end{abstract}

Methods: GSH content, O2- production, and B220, HSP70, Fas and FasL membrane expression was measured by flow cytometry. Subcellular localization of B220 was determined by imaging flow cytometry. Cell death was analyzed by morphological changes, annexin $V$ and propidium iodide staining, and caspase 8 and 9 activation. B220 mRNA expression was analyzed by RT-PCR. Activated NF-KB p50 was quantified by a DNA binding ELISA.

Results: We selected human (Jurkat, Jurkat variant J45.01, HPB-ALL) and mouse (EL-4, BW5147, L1210) T-cell lines for their marked differences in $\mathrm{As}_{2} \mathrm{O}_{3}$ sensitivity over a large range of doses ( 1 to $20 \mu \mathrm{M}$ ). Differences in redox status cannot explain the dramatic differences in $\mathrm{As}_{2} \mathrm{O}_{3}$ sensitivity observed among the T-cell lines. Unexpectedly, we found that $\mathrm{B} 220$ is differentially induced on $\mathrm{As}_{2} \mathrm{O}_{3}$-treated T-cell lines. $\mathrm{As}_{2} \mathrm{O}_{3}$ treatment for $24 \mathrm{~h}$ induced low (HPB-ALL), intermediate (Jurkat) and high (EL-4, BW5147) levels of B220 membrane expression, membrane-bound HSP70 and cell death, but inhibited NF-KB p50 nuclear translocation. When high levels of B220 expression were achieved with low doses of $\mathrm{As}_{2} \mathrm{O}_{3}$, the T-cell lines died by apoptosis only. When high doses of $\mathrm{As}_{2} \mathrm{O}_{3}$ were required to induce B220 expression, leukemic T cells died by both apoptosis and necrosis.

Conclusions: Cellular redox status is not essential for $\mathrm{As}_{2} \mathrm{O}_{3}$ sensitivity of leukemic $\mathrm{T}$ cells, suggesting the existence of additional factors determining their sensitivity to $\mathrm{As}_{2} \mathrm{O}_{3}$ cytotoxicity. Phosphatase $\mathrm{B} 220$ could be such a factor of sensitivity. $\mathrm{As}_{2} \mathrm{O}_{3}$ treatment inhibits NF- $\mathrm{KB}$ p50 nuclear translocation, and induces B220 expression and cell death in a dose and time dependent manner. The levels of B220 induction on leukemic T cells strictly correlate with both the extent and form of cell death, B220 might therefore play a checkpoint role in death pathways.

Keywords: $\mathrm{As}_{2} \mathrm{O}_{3}$-based therapy, Leukemia, T lymphocyte, Membrane tyrosine-phosphatase B220/CD45R, Membrane-bound HSP70, Fas/Fas ligand pathway, Cell death, Caspase activation, NF-kB p50

\footnotetext{
* Correspondence: pierre.bobe@u-psud.fr

'Institut Jacques Monod, CNRS, Université Paris Diderot, Paris, France

${ }^{3}$ INSERM U757, Université Paris-Sud, Orsay, France

Full list of author information is available at the end of the article
} 


\section{Background}

Arsenic trioxide $\left(\mathrm{As}_{2} \mathrm{O}_{3}\right)$ shows impressive efficacy in the treatment of patients with acute promyelocytic leukemia (APL) [1-4]. $\mathrm{As}_{2} \mathrm{O}_{3}$ induces clinical remission in APL patients by multiple mechanisms [5]. $\mathrm{As}_{2} \mathrm{O}_{3}$ promotes cell differentiation at low concentrations [6,7], whereas it induces apoptosis at higher concentrations [8]. The high sensitivity of the APL cell line $\mathrm{NB} 4$ to $\mathrm{As}_{2} \mathrm{O}_{3}$ induced cytotoxicity is associated to its low content of reduced glutathione (GSH) and increased production of reactive oxygen species (ROS) [9-11]. Although most studies have been focused on the APL, $\mathrm{As}_{2} \mathrm{O}_{3}$ could be beneficial against various hematopoietic malignancies and solid tumors [12]. Moreover, we have shown that $\mathrm{As}_{2} \mathrm{O}_{3}$ also possesses immunomodulatory properties, and might be a therapeutic agent for autoimmune diseases. Indeed, $\mathrm{As}_{2} \mathrm{O}_{3}$ selectively eliminates the pathogenic B220expressing double negative (DN) $\mathrm{CD} 4^{-} \mathrm{CD}^{-} \mathrm{T}$ cells that accumulate in autoimmune MRL/lpr mice due to the $l p r$ mutation of the death receptor Fas $[13,14]$.

In normal murine and human T cells, $\mathrm{CD}^{+}$and $\mathrm{CD}^{+}$ effector T cells massively induce the expression of transmembrane tyrosine phosphatase B220 before undergoing apoptosis by the Fas/Fas ligand (FasL) pathway [15,16]. In Fas-deficient mice and patients, $\mathrm{CD}^{+}$and $\mathrm{CD}^{+}$effector $\mathrm{T}$ cells also express the B220 molecules at their surface, but then they downregulate their CD4 or CD8 molecules while maintaining B220 plasma membrane expression. B220 (or CD45RABC) is one of the five isoforms of the transmembrane tyrosine phosphatase CD45 found on lymphocytes. CD45 isoforms are generated by cell-type and activation-state specific alternative splicing of exons $4 / \mathrm{A}, 5 / \mathrm{B}$, and $6 / \mathrm{C}$ encoding domains at the $\mathrm{NH}_{2}$-terminus. Naive $\mathrm{T}$ cells express high molecular weight CD45 isoforms (CD45RA or CD45RB) containing the $\mathrm{A}$ domain in humans or the $\mathrm{B}$ domain in mice whereas effector/memory $\mathrm{T}$ cells expressed the low molecular weight isoform CD45RO lacking extracellular domains A, B and C. All CD45 isoforms share the same intracellular region, which contains two phosphatase domains. Although the function of each isoform remains unknown, it is well established that CD45 phosphatase activity is crucial for lymphocyte development, and antigen and cytokine receptor signaling [17-19]. CD45 might also regulate apoptosis of $\mathrm{T}$ and B lymphocytes [20-22].

In this study, we found that murine (EL-4, BW5147, L1210) and human (Jurkat, CD45-deficient Jurkat variant, HPB-ALL) leukemic T-cell lines dramatically differed in their sensitivity to $\mathrm{As}_{2} \mathrm{O}_{3}$-induced cell death. In contrast with previous findings in APL cell line NB4 $[9,10]$, these differences in $\mathrm{As}_{2} \mathrm{O}_{3}$ sensitivity are independent of intracellular GSH content and $\mathrm{O}_{2}{ }^{-}$production. Unexpectedly, we found that $\mathrm{As}_{2} \mathrm{O}_{3}$ differently induced B220 cell surface expression in the leukemic
T-cell lines in a dose- and time-dependent manner. Moreover, the levels of B220 expression correlated with the sensitivity of these T-cell lines to $\mathrm{As}_{2} \mathrm{O}_{3}$. Induction of B220 membrane expression by $\mathrm{As}_{2} \mathrm{O}_{3}$ treatment is reminiscent of that observed on antigen-activated normal T-cell blasts before undergoing apoptosis $[15,16]$. Therefore, the leukemic T-cell lines were activated with calcium ionophore A23187, which triggers both cell activation and cell death. Calcium ionophore A23187 also induced B220 expression and cell death, but with reverse efficiencies in the leukemic T-cell lines compared to $\mathrm{As}_{2} \mathrm{O}_{3}$. In addition, T-cell lines treated with A23187 most probably died by an activation-induced cell death mechanism since the T-cell activation marker CD69 is expressed before B220 expression and cell death. In contrast, CD69 was not detected on $\mathrm{As}_{2} \mathrm{O}_{3}$-treated cells, indicating that $\mathrm{B} 220$ expression occurs independently of leukemic T-cell activation. Surprisingly, we found that B220 is expressed constitutively on L1210 T cells. L1210 cells were highly sensitive to A23187 treatment whereas they were highly resistant to $\mathrm{As}_{2} \mathrm{O}_{3}$ cytotoxicity, indicating that the constitutive high-level expression of B220 did not favor cell death triggered by $\mathrm{As}_{2} \mathrm{O}_{3}$. B220 induction on the T-cell lines after treatment with $\mathrm{As}_{2} \mathrm{O}_{3}$ or calcium ionophore A23187 strictly correlates with sensitivity to cell death, emphasizing the role of B220 as a proapoptotic factor. However, our data indicate that $\mathrm{As}_{2} \mathrm{O}_{3}$ and $\mathrm{A} 23187$ trigger B220 induction and cell death through different upstream signaling pathways. Different signaling pathways, such as the c-Jun $\mathrm{NH}_{2}$-terminal kinase, have been implicated as mediators of the cytotoxic effects of $\mathrm{As}_{2} \mathrm{O}_{3}$ in the APL cell line NB4 [23]. Here, we show that high induction of B220 expression on leukemic $\mathrm{T}$ cells is a determining factor leading to $\mathrm{As}_{2} \mathrm{O}_{3}$-triggered cell death. Thus we hypothesize that B220 might play a checkpoint role in death pathways.

\section{Results}

Human and mouse leukemic T-cell lines exhibit different sensitivities to $\mathrm{As}_{2} \mathrm{O}_{3}$-induced growth inhibition and cytotoxicity

In addition to APL-derived NB4 cells, $\mathrm{As}_{2} \mathrm{O}_{3}$ kills various cancer cell types [12]. However, $\mathrm{As}_{2} \mathrm{O}_{3}$ sensitivity varies considerably among tumor cell lines. In the present study, we determined the sensitivity to $\mathrm{As}_{2} \mathrm{O}_{3}$-induced cytotoxicity and growth inhibition of human (Jurkat and HPBALL) and murine (EL-4, BW5147 and L1210) leukemic T-cell lines. The five T-cell lines along with APL-derived NB-4, known for its high sensitivity to $\mathrm{As}_{2} \mathrm{O}_{3}$ cytotoxicity, were treated with $\mathrm{As}_{2} \mathrm{O}_{3}$ in doses ranging from 1 to $20 \mu \mathrm{M}$ for 12,24 and $48 \mathrm{~h}$. Then, the percentage of living cells was determined by Annexin $\mathrm{V}$ and propidium iodide (PI) staining, and flow cytometry. We rapidly abandoned treatments for $12 \mathrm{~h}$ and $48 \mathrm{~h}$. Indeed, 100\% EL-4 and 
BW5147 cells were killed after $24 \mathrm{~h}$ of treatment with low doses of $\mathrm{As}_{2} \mathrm{O}_{3}$, whereas HPB-ALL and L1210 cells showed no sensitivity to $\mathrm{As}_{2} \mathrm{O}_{3}$ cytotoxicity before $24 \mathrm{~h}$ of treatment, even with high doses (data not shown). Because 24 h of treatment was the optimal time to observe significant differences in $\mathrm{As}_{2} \mathrm{O}_{3}$ cytotoxicity among $\mathrm{T}$-cell lines, this duration was used in subsequent experiments. Sensitivity to $\mathrm{As}_{2} \mathrm{O}_{3}$ varied considerably among the T-cell lines (Figure 1A). While around 3\% NB4, 6\% EL-4 and 13\% BW5147 cells remained alive (Annexin $\mathrm{V}^{-}$and $\left.\mathrm{PI}^{-}\right)$at a concentration of $4 \mu \mathrm{M} \mathrm{As} \mathrm{O}_{3}$, remarkably, the percentages of living cells were around 65\% for Jurkat cells, and between $80 \%$ and $90 \%$ for HPB-ALL and L1210 cells (Figure 1A). In addition, even at a dose of $20 \mu \mathrm{M}$, 20\% L1210 and 40\% HPB-ALL cells remained Annexin $\mathrm{V}^{-}$ and $\mathrm{PI}^{-}$(Figure 1A). The marked differences in $\mathrm{As}_{2} \mathrm{O}_{3}$ sensitivity among the T-cell lines can also be shown by calculating the concentration of $\mathrm{As}_{2} \mathrm{O}_{3}$ that killed $50 \%$ of the cells ( $\mathrm{IC}_{50}$ value). The $\mathrm{IC}_{50}$ value of $\mathrm{As}_{2} \mathrm{O}_{3}$ was $1.5 \mu \mathrm{M}$ for EL-4, $2.5 \mu \mathrm{M}$ for BW5147, $6 \mu \mathrm{M}$ for Jurkat, $13 \mu \mathrm{M}$ for L1210 and $15 \mu \mathrm{M}$ for HPB-ALL cells compared with $1.5 \mu \mathrm{M}$ for the highly sensitive APL-derived NB4 cells (Figure $1 \mathrm{~A}$ ). $\mathrm{As}_{2} \mathrm{O}_{3}$ cytotoxicity was also evaluated through flow cytometric analysis of physical characteristics of $\mathrm{As}_{2} \mathrm{O}_{3}$-treated $\mathrm{T}$-cell lines using forward (FSC) and side (SSC) scatters since dying or dead cells have lower FSC and higher SSC than living cells. Depending upon the dose of $\mathrm{As}_{2} \mathrm{O}_{3}$, two populations were observed on the dot plots for FSC $v s$. SSC. The one containing large cells (region R2) encompassed live cells, and the other containing smaller cells (region R1) encompassed dying/ dead cells (Additional file 1: Figure S1A). We observed that $50 \%$ of the cells of region $\mathrm{R} 2$ shifted to region $\mathrm{R} 1$ at 2.5 to $3 \mu \mathrm{M} \mathrm{As} \mathrm{O}_{3}$ for BW5147 and EL-4 cells, $6 \mu \mathrm{M}$ for Jurkat cells, and $15 \mu \mathrm{M}$ for L1210 and HPB-ALL cells compared with $1.5 \mu \mathrm{M}$ for the APL cell line NB4 (Figure $1 \mathrm{~B}$ ). In parallel, we determined $\mathrm{As}_{2} \mathrm{O}_{3}$-induced cell growth inhibition by counting the total cell number in each condition using flow cytometry. $\mathrm{IC}_{50}$ value for growth inhibition was around $1 \mu \mathrm{M}$ for NB4 and EL-4 cells, $3.5 \mu \mathrm{M}$ for BW5147 cells, $8 \mu \mathrm{M}$ for Jurkat, $15 \mu \mathrm{M}$ for L1210 and HPB-ALL cells. In summary, EL-4 and BW5147 cells, and to a lesser extent Jurkat cells, are among the most sensitive $\mathrm{T}$-cell lines to $\mathrm{As}_{2} \mathrm{O}_{3}$-induced cell growth inhibition and cytotoxicity, whereas L1210 and HPB-ALL cells are the most resistant.

\section{Lack of evidence for the implication of $\mathrm{GSH}$ and $\mathrm{O}_{2}{ }^{-}$in $\mathrm{As}_{2} \mathrm{O}_{3}$-induced cytotoxicity in $\mathrm{T}$-cell lines}

$\mathrm{As}_{2} \mathrm{O}_{3}$ is able to impair the function of the mitochondrial respiratory chain, leading to increased $\mathrm{O}_{2}{ }^{-}$production [24]. $\mathrm{O}_{2}{ }^{-}$is neutralized by intracellular $\mathrm{GSH}$, which is the major antioxidant produced by the cell. The detoxification function of intracellular GSH also includes the cellular efflux of $\mathrm{As}_{2} \mathrm{O}_{3}$ [25]. Therefore, we performed flow cytometry analysis of intracellular GSH content and $\mathrm{O}_{2}{ }^{-}$production in the $\mathrm{T}$-cell lines before and after treatment with $\mathrm{As}_{2} \mathrm{O}_{3}$ (Figure 2). APL-derived NB4 cells were used as a reference because intracellular redox status has been shown to be important in APL sensitivity to $\mathrm{As}_{2} \mathrm{O}_{3}[9,10]$. As observed in many cancer cells [25], the untreated cell lines showed considerable heterogeneity in the intrinsic levels of $\mathrm{O}_{2}{ }^{-}$production, with untreated NB4 cells displaying the lower level of $\mathrm{O}_{2}{ }^{-}$ (Figure 2A). In $\mathrm{As}_{2} \mathrm{O}_{3}$-treated APL-derived NB4 cells, $\mathrm{O}_{2}{ }^{-}$production increased with the dose of arsenic (Figure 2B). In $\mathrm{As}_{2} \mathrm{O}_{3}$-sensitive EL-4 and BW5147 T-cell lines, $\mathrm{O}_{2}^{-}$production was not increased by $\mathrm{As}_{2} \mathrm{O}_{3}$ treatment even at the high dose of $15 \mu \mathrm{M}$ (Figure 2B). In contrast, in $\mathrm{As}_{2} \mathrm{O}_{3}$-resistant Jurkat and $\mathrm{L} 1210$ T-cell lines, $\mathrm{O}_{2}{ }^{-}$ production was markedly increased (Figure $2 \mathrm{~B}$ ). Therefore, these data indicate that the differences in $\mathrm{As}_{2} \mathrm{O}_{3}$ sensitivity between EL-4, BW5147, Jurkat and L1210 cells are not directly linked to increased production of $\mathrm{O}_{2}{ }^{-}$.

As expected, $\mathrm{As}_{2} \mathrm{O}_{3}$-sensitive APL-derived NB4 cells displayed extremely low level of intrinsic GSH content (Figure 2A). In contrast, the intrinsic GSH content in untreated EL-4 and BW5147 T-cell lines were significantly higher than in untreated HPB-ALL and L1210 T-cell lines (Figure 2A), although L1210 and HPB-ALL cells were considerably more resistant to the cytotoxic effect of $\mathrm{As}_{2} \mathrm{O}_{3}$ than EL-4 and BW5147 cells. At the dose of $1 \mu \mathrm{M} \mathrm{As} \mathrm{A}_{2} \mathrm{O}_{3}$, levels of GSH were unaffected by the treatment in the extremely sensitive NB4 cells, but were markedly decreased in $\mathrm{As}_{2} \mathrm{O}_{3}$-sensitive BW5147 $\mathrm{T}$ cells and also, although to a lesser extent, in the $\mathrm{As}_{2} \mathrm{O}_{3}$-resistant Jurkat cells (Figure 2B). Furthermore, in the extremely resistant L1210 T cells, GSH production was unchanged even at the high dose of $15 \mu \mathrm{M} \mathrm{As} \mathrm{O}_{2} \mathrm{O}_{3}$ (Figure 2B). Therefore, our data indicate that intracellular GSH content alone cannot account for the differences in $\mathrm{As}_{2} \mathrm{O}_{3}$ sensitivity observed among the five T-cell lines.

\section{Induction of $\mathrm{B} 220 / \mathrm{CD} 45 \mathrm{R}$ expression on $\mathrm{As}_{2} \mathrm{O}_{3}$-treated human and murine T-cell lines}

Normal effector $\mathrm{T}$ cells undergoing apoptosis at the end of an immune response express B220 on their cell surface. These apoptotic $B 220^{+} \mathrm{T}$ cells are solely found within the FSC $^{\text {int/low }}$ SSC $^{\text {high }}$ subset by flow cytometry analysis $[15,16]$. Interestingly, we observed that $\mathrm{As}_{2} \mathrm{O}_{3}$ is also able to induce cell-surface expression of B220 on EL-4, BW5147, Jurkat and HPB-ALL T-cell lines in a dosedependent manner (Figure 3). However, B220 expression levels differed significantly among these four T-cell lines. Thus, a significantly higher percentage of EL-4 cells, and to a lesser extent of BW5147 and Jurkat cells, expressed B220 compared to HPB-ALL cells (for instance, see $2 \mu \mathrm{M}$ 


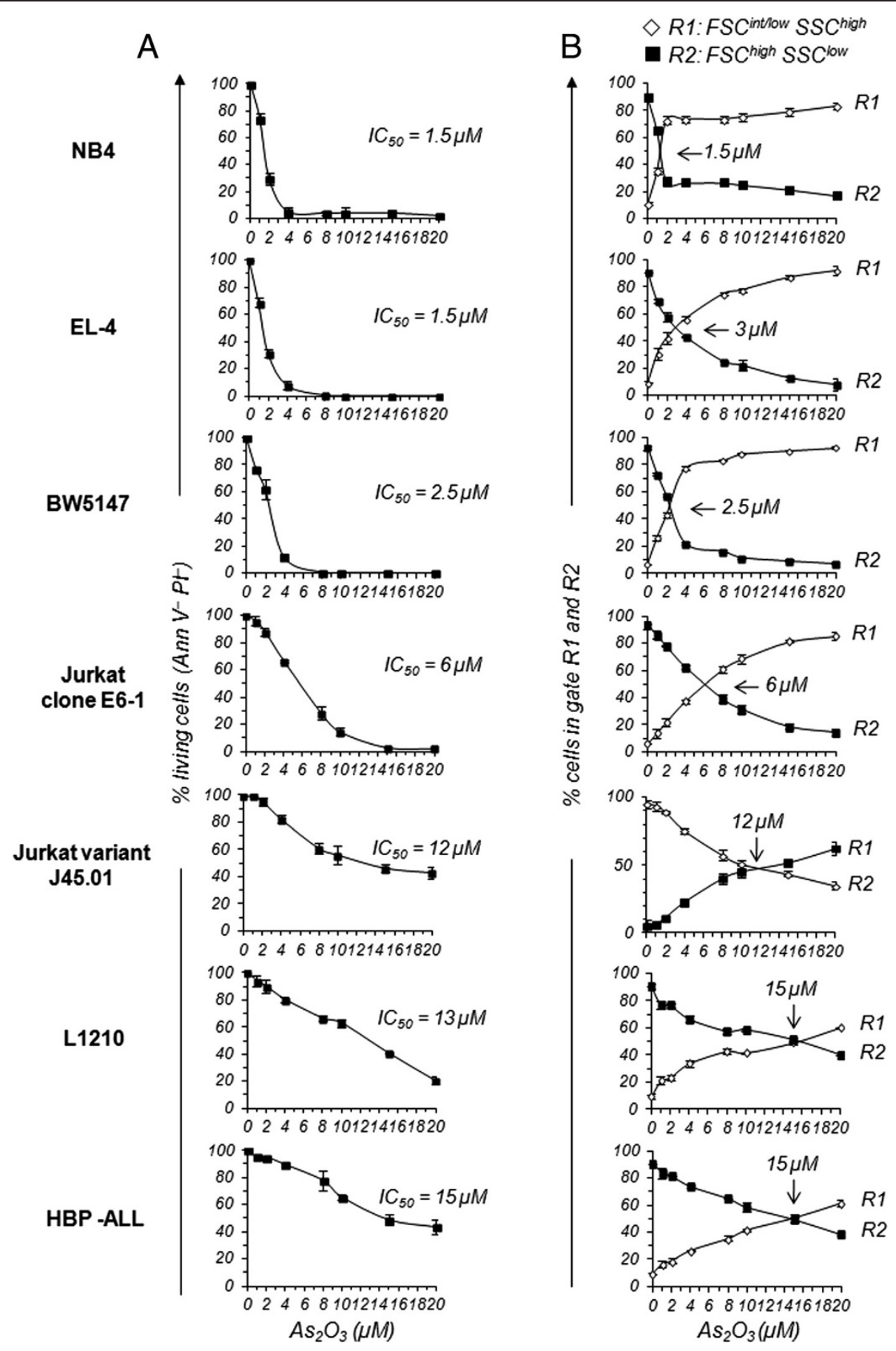

Figure 1 Viability and cell morphology of various T-cell lines cells upon $\mathrm{As}_{2} \mathrm{O}_{3}$-treatment. (A) APL-derived NB4 cells as well EL-4, BW5147, L1210, Jurkat (clone E6-1), CD45-deficient Jurkat variant (J45.01) and HPB-ALL T-cell lines were treated with $\mathrm{As}_{2} \mathrm{O}_{3}$ for $24 \mathrm{~h}$ with doses ranging from 1 to $20 \mu \mathrm{M}$. T-cell lines were then stained with Annexin $\mathrm{V}$ and PI, and the percentages of living cells (Ann $\mathrm{V}^{-} \mathrm{PI}^{-}$) determined by flow cytometry. At least 20,000 events were analyzed for each sample. Graphs show mean percentages \pm SE of Ann $\mathrm{V}^{-} \mathrm{Pl}^{-}$cells from more than 4 independent experiments. $I C_{50}$ in the graphs indicates the concentration of $\mathrm{As}_{2} \mathrm{O}_{3}$ that kills $50 \%$ of the cells. (B) Cells were analyzed by flow cytometry

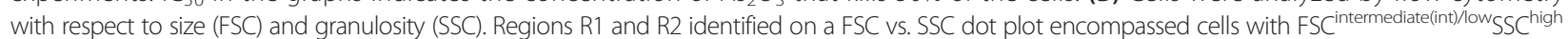
and FSChigh $S S^{\text {low }}$, respectively. At least 20,000 events were analyzed for each sample. Graphs show mean percentages \pm SE of cells located in region R1 $(\vartheta)$ and R2 ( $\mathbf{a})$ at the indicated concentration of $\mathrm{As}_{2} \mathrm{O}_{3}$. Numbers in the graphs indicate the concentration of $\mathrm{As}_{2} \mathrm{O}_{3}$ at which $50 \%$ of the cells shifted from region R2 to region R1. Four independent experiments were performed for NB4 and J45.01 cells, and more than 10 for EL-4, BW5147, L1210, Jurkat and HPB-ALL cells. 


\section{A Intrinsic levels}
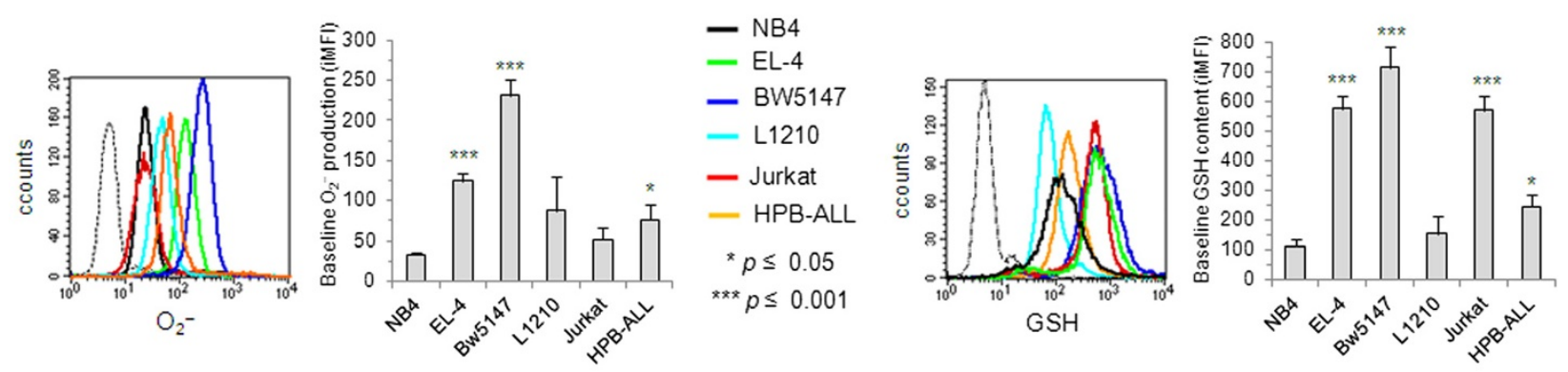

\section{$\mathrm{B} \mathrm{As}_{2} \mathrm{O}_{3}$-modulated levels}
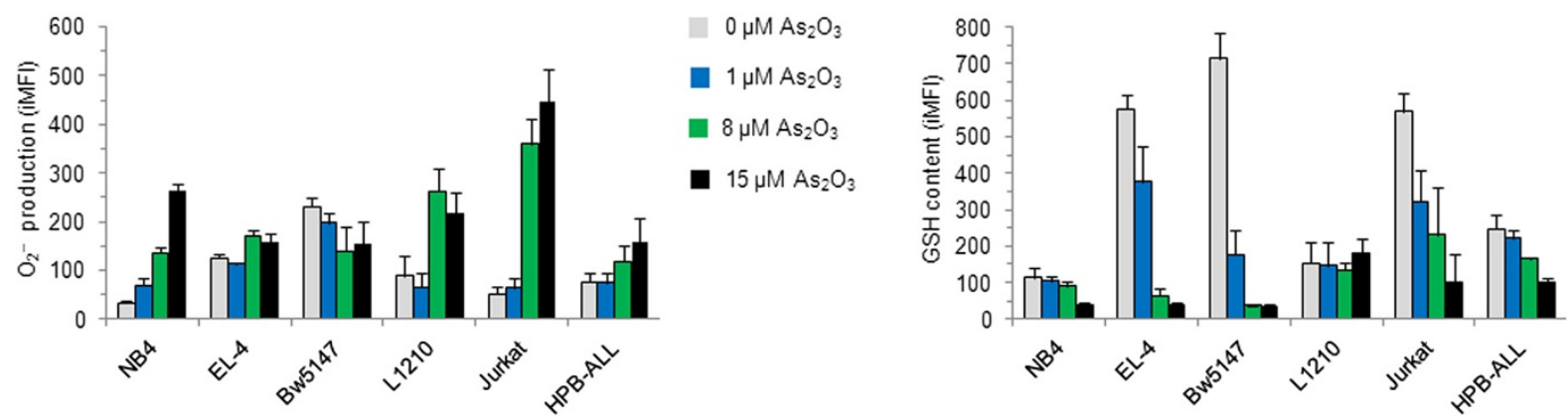

Figure 2 Intracellular levels of $\mathrm{O}_{2}{ }^{-}$and GSH in cell lines before and after $\mathrm{As}_{2} \mathrm{O}_{3}$ treatment. Intracellular levels of $\mathrm{O}_{2}{ }^{-}$and $\mathrm{GSH}$ were measured using CMFDA or DHE fluorescent probes and flow cytometry. (A) Untreated APL-derived NB4 cells and T-cell lines were examined for intrinsic levels of $\mathrm{O}_{2}^{-}$production and GSH content. Histograms obtained with specific fluorescent probes (colored histograms) are overlaid on fluorescence histograms of unstained cells (black dotted histogram). A total of 20,000 events were analyzed for each histogram. Graphs report mean \pm SE ( $n=3$ independent experiments) of integrated MFI values for $\mathrm{O}_{2}^{-}$production and GSH content. The integrated MFI is calculated by multiplying the frequency of positive cells by the MFI of $\mathrm{O}_{2}{ }^{-}$and $\mathrm{GSH}$. Asterisks denote statistically significant differences for levels of $\mathrm{GSH}_{\mathrm{H}}$ or $\mathrm{O}_{2}{ }^{-}$ between leukemic T-cell lines and APL-derived NB4 cells: ${ }^{*} p \leq 0.05 ;{ }^{* * *} p \leq 0.001$. (B) $\mathrm{O}_{2}^{-}$production and GSH content were examined in APL-derived NB4 cells and T-cell lines treated with $1 \mu \mathrm{M}$ to $15 \mu \mathrm{M} \mathrm{As} \mathrm{O}_{3}$ for $24 \mathrm{~h}$. Graphs report mean $\pm \mathrm{SE}$ ( $\mathrm{n}=3$ independent experiments) of integrated MFI values for $\mathrm{O}_{2}^{-}$production and GSH content.

dose in Table 1 or $4 \mu \mathrm{M}$ dose in Figure 3). B220 leukemic $\mathrm{T}$ cells were found in both gate R1 and R2 that contained FSC $^{\text {int/low }}$ SSC $^{\text {high }}$ dying cells (Figure 3 ) and FSC ${ }^{\text {high }}$ SSC $^{\text {low }}$ living cells (data not shown), respectively, although the numbers were significantly higher in gate $\mathrm{R} 1 . \mathrm{As}_{2} \mathrm{O}_{3}$ also induces B220 expression at the mRNA level in a dose- and time-dependent manner. High levels of B220 mRNA were found in EL-4 and BW5147 within $3 \mathrm{~h}$ of treatment with $1 \mu \mathrm{M} \mathrm{As}_{2} \mathrm{O}_{3}$. Higher doses of $\mathrm{As}_{2} \mathrm{O}_{3}$ (e.g., $4 \mu \mathrm{M}$ for $3 \mathrm{~h}$ ) or longer treatment (e.g., $1 \mu \mathrm{M}$ for $9 \mathrm{~h}$ ) resulted in increased levels of B220 mRNA (Additional file 1: Figure S1C). In contrast, $\mathrm{As}_{2} \mathrm{O}_{3}$ did not induce $\mathrm{B} 220$ expression on APLderived NB4 cells (data not shown). To confirm that $\mathrm{A}_{2} \mathrm{O}_{3}$-induced cytotoxicity in leukemic $\mathrm{T}$ cells and B220 expression are mechanistically related, we analyzed CD45deficient Jurkat cells (clone J45.01) for their $\mathrm{As}_{2} \mathrm{O}_{3}$ sensitivity over a large range of doses (1 to $20 \mu \mathrm{M})$. As shown in Additional file 1: Figure S1B, J45.01 T-cell line displays a strong reduction in the expression level of CD45 per cell (MFI) compared to wild-type Jurkat cells (MFI J45.01: 40;
MFI Jurkat: 1528; MFI isotype control: 5 ). The $\mathrm{IC}_{50}$ value for cytotoxicity was around $12 \mu \mathrm{M}$ for J45.01 compared to $6 \mu \mathrm{M}$ for wild-type Jurkat cells, corroborating the critical role of the $\mathrm{B} 220$ isoform of $\mathrm{CD} 45$ in the resistance/sensitivity of leukemic T cells to $\mathrm{As}_{2} \mathrm{O}_{3}$.

Unexpectedly, we also found that L1210 T cells constitutively express B220 at the plasma membrane. L1210 cells undoubtedly belong to the T-cell lineage because they coexpress the mouse pan T-cell marker CD90 (Additional file 2: Figure S2A). To the best of our knowledge, we have shown for the first time that B220 can be constitutively expressed at high levels on T cells, in the absence of external stimulation. $\mathrm{As}_{2} \mathrm{O}_{3}$ treatment did not change either the percentages of $\mathrm{B} 220^{+} \mathrm{L} 1210$ cells, or the expression level of B220 per cell (MFI) (Additional file 2: Figure S2B).

Furthermore, we have compared the subcellular localization and distribution of B220 molecules that were either constitutively expressed on L1210 cells or $\mathrm{As}_{2} \mathrm{O}_{3}$-induced on EL-4 cells, using ImageStream device, which allows simultaneous flow cytometry and 


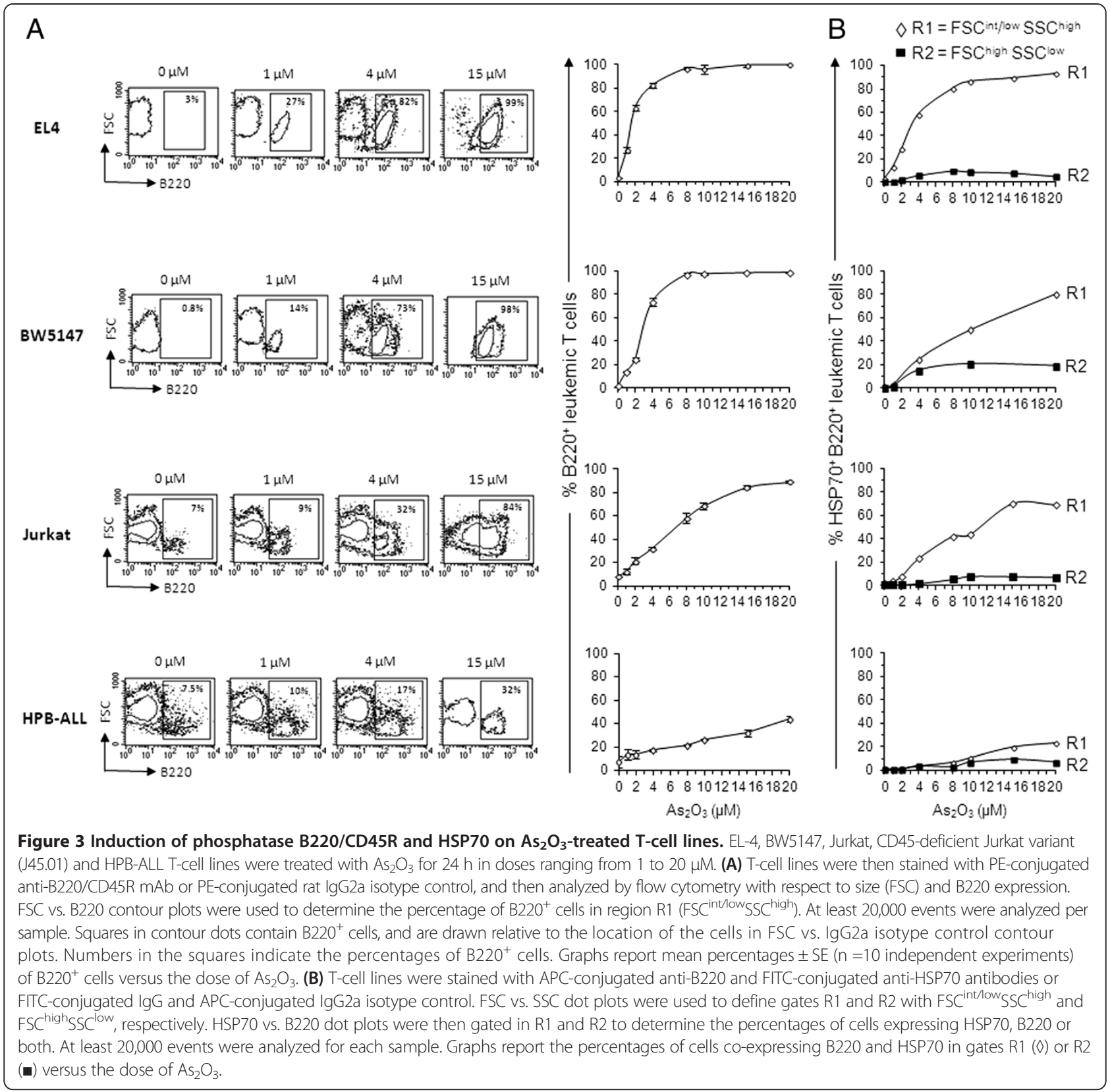

fluorescence microscopy analysis on a large numbers of cells. Whole cell and nuclear boundaries were identified using brightfield image and DAPI staining, respectively. In the absence of $\mathrm{As}_{2} \mathrm{O}_{3}$ treatment, no labeling with antiB220/CD45R mAb was observed in EL-4 cells (Figure 4A). In contrast, in untreated $\mathrm{L} 1210$ cells and $2 \mu \mathrm{M} \mathrm{As} \mathrm{O}_{3}$ treated EL-4 cells, B220 molecules were expressed at high levels with a restricted localization to the cell surface (Figure 4A and B), confirming the results obtained by flow cytometry. However, B220 molecules appeared less uniformly distributed over the plasma membrane of EL-4 cells (Figure 4A) than L1210 cells (Figure 4B). Thus, L1210 cells showed a uniform fluorescence at the periphery of the cell, whereas a variable number of bright spots of fluorescence were distributed at the periphery of EL-4 cells.

\section{Duration of B220/CD45R membrane expression after $\mathrm{As}_{2} \mathrm{O}_{3}$ treatment}

To determine the duration of B220 expression following $\mathrm{As}_{2} \mathrm{O}_{3}$ treatment, EL-4 and Jurkat cells were cultured in the presence of 1 to $8 \mu \mathrm{M} \mathrm{As} \mathrm{O}_{3}$ for $24 \mathrm{~h}$. Cells were then extensively washed to eliminate $\mathrm{As}_{2} \mathrm{O}_{3}$, and cultured in complete medium for 9 additional days. $\mathrm{As}_{2} \mathrm{O}_{3}$ treatment for $24 \mathrm{~h}$ induced B220 expression in a dosedependent manner (Additional file 3: Figure S3, graphs), 
Table 1 Opposite effects of $\mathrm{As}_{2} \mathrm{O}_{3}$ or Calcium ionophore $\mathrm{A} 23187$ on a panel of leukemic T-cell lines

\begin{tabular}{|c|c|c|c|c|c|c|c|c|}
\hline \multirow[b]{2}{*}{ T-cell lines } & \multicolumn{4}{|c|}{$\mathrm{As}_{2} \mathrm{O}_{3}\left(2 \mu \mathrm{M}^{*}\right)$} & \multicolumn{4}{|c|}{ Calcium ionophore A23187 (100 nM) } \\
\hline & $\begin{array}{c}\text { B220 } \\
\text { upregulation }^{* *}\end{array}$ & $\begin{array}{c}\text { CD69 } \\
\text { upregulation** }\end{array}$ & $\begin{array}{c}\text { HSP70 } \\
\text { upregulation }^{* *}\end{array}$ & $\begin{array}{c}\text { Cell } \\
\text { death*** }\end{array}$ & $\begin{array}{c}\text { B220 } \\
\text { upregulation }^{* *}\end{array}$ & $\begin{array}{c}\text { CD69 } \\
\text { upregulation** }\end{array}$ & $\begin{array}{c}\text { HSP70 } \\
\text { upregulation** }^{*}\end{array}$ & $\begin{array}{c}\text { Cell } \\
\text { death }\end{array}$ \\
\hline EL-4 & 63 & No & 35 & 70 & 7 & Yes & no & 1 \\
\hline BW5147 & 30 & No & 20 & 39 & 19 & Yes & no & 25 \\
\hline $\begin{array}{c}\text { Jurkat clone } \\
\text { E6-1 }\end{array}$ & 22 & No & 10 & 12 & 30 & Yes & no & 28 \\
\hline HPB-ALL & 10 & No & 3 & 5 & 80 & Yes & no & 75 \\
\hline L1210 & $\begin{array}{l}\text { Constitutive } \\
\text { expression }\end{array}$ & No & 5 & 10 & $\begin{array}{l}\text { Constitutive } \\
\text { expression }\end{array}$ & Yes & no & 55 \\
\hline
\end{tabular}

*a clinically relevant concentration of $\mathrm{As}_{2} \mathrm{O}_{3}$.

**percentage of positive cells determined by flow cytometry.

***percentage of $\mathrm{PI}^{+}$cells (either Annexin $\mathrm{V}^{-}$or Annexin $\mathrm{V}^{+}$) determined by flow cytometry.

particularly on EL-4 cells, corroborating the findings reported in Figure 3. On day 1 post-treatment, and at concentrations of $1 \mu \mathrm{M}$ and $8 \mu \mathrm{M} \mathrm{As} \mathrm{AO}_{3}$, the percentages of $\mathrm{B} 220^{+}$EL-4 cells were around 50\% and 95\%, respectively. One week later, the percentage of $\mathrm{B}_{2} 20^{+}$EL-4 cells fell below $15 \%$ at $1 \mu \mathrm{M} \mathrm{As} \mathrm{O}_{3}$, whereas it remained at $90 \%$ at the concentration of $8 \mu \mathrm{M}$ (Additional file 3: Figure S3, graphs). Likewise in Jurkat cells, on day 7 post-treatment, around $50 \%$ of cells treated with $8 \mu \mathrm{M} \mathrm{As} \mathrm{As}_{2} \mathrm{O}_{3}$ expressed B220 (Additional file 3: Figure S3, dot plots and graph), while B220 could no longer be detected on Jurkat cells treated with 1 to $4 \mu \mathrm{M} \mathrm{As}{ }_{2} \mathrm{O}_{3}$ (Additional file 3: Figure S3, graph). The loss of B220 expression on EL-4 and Jurkat cells was accompanied by a decreased cell number in gate $\mathrm{R} 1$ (FSC $^{\text {int/low }} \mathrm{SSC}^{\text {high }}$ ) and an expansion of viable cells in gate R2 (Additional file 3: Figure S3, dot plots, see days 7 and 9). The duration of $\mathrm{B} 220$ expression in gate $\mathrm{R} 1$ was dependent on the dose of $\mathrm{As}_{2} \mathrm{O}_{3}$ treatment. Thus, a longer duration of B220 expression was associated with a higher concentration of $\mathrm{As}_{2} \mathrm{O}_{3}$, and a higher number of $\mathrm{B} 220^{+}$ cells at the time of $\mathrm{As}_{2} \mathrm{O}_{3}$ removal. The decrease in the percentages of $\mathrm{B}_{2} 2 \mathrm{O}^{+}$cell population could be due to the
A EL-4 T cells
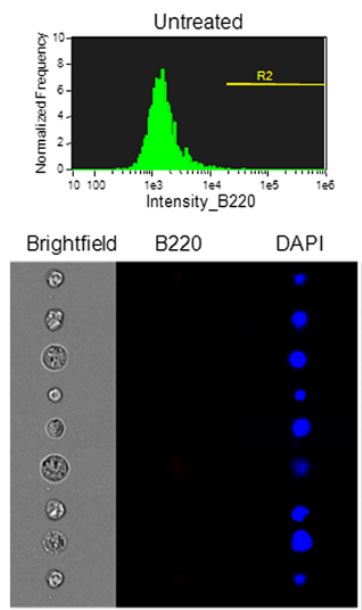
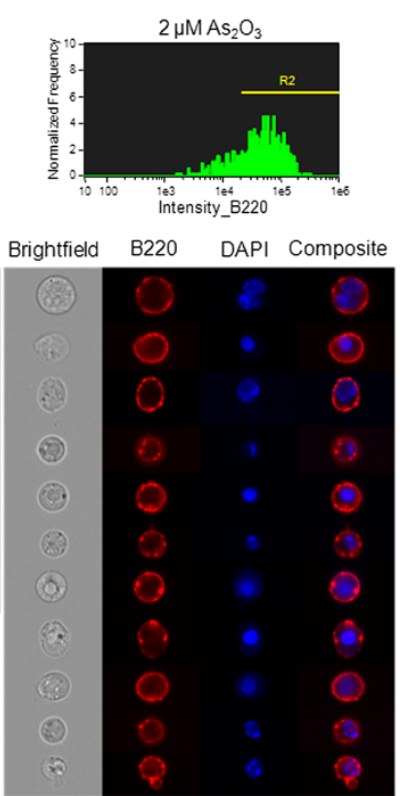

B L1210 T cells
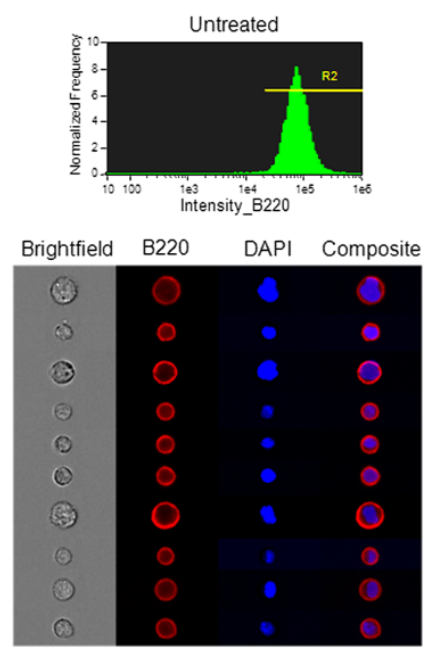

Figure 4 Subcellular localization of constitutively expressed and $\mathrm{As}_{2} \mathrm{O}_{3}$-induced $\mathrm{B220/CD45R}$ molecules. Untreated and $\mathrm{As}_{2} \mathrm{O}_{3}$-treated ( $2 \mu \mathrm{M}$ for 24 h) EL-4 cells (panel A), and untreated L1210 cells (panel B) were stained with PE-conjugated anti-B220/CD45R mAb and DAPI nuclear dye. Samples were then analyzed on the ImageStream system. At least 10,000 images were collected per sample at 40X and 60X magnification. B220-PE positive cells were gated (gate R2) according to the principle for flow cytometry as shown on histogram. Background staining was determined using PE-conjugated rat IgG2a isotype control. Representative cell images of brightfield illumination, B220-PE (red) and DAPI (blue) fluorescence and composite images of B220/DAPI are shown on panel $\mathbf{A}$ and $\mathbf{B}$. 
death of $\mathrm{B}^{2} 20^{+}$cells, and/or the proliferation of the remaining $\mathrm{B}^{2} 20^{-}$cells. However, even on day 9 posttreatment, EL-4 and Jurkat cells had not fully recovered their initial proliferative capacity (data not shown). Our data suggest that dead $\mathrm{B}_{22} 20^{+} \mathrm{T}$ cells release their $\mathrm{As}_{2} \mathrm{O}_{3}$ content into the medium, which is subsequently recaptured by living B220-negative T cells. The amount of released $\mathrm{As}_{2} \mathrm{O}_{3}$ is dependent on the dose used at the time of treatment.

\section{Expression of membrane-bound $\mathrm{HSP} 70$ on $\mathrm{As}_{2} \mathrm{O}_{3}$-treated T-cell lines parallels the induction of B220/CD45R}

Heat shock protein 70 (HSP70) is upregulated intracellularly in respond to a variety of stresses including chemical or chemotherapeutic agents. HSP70 proteins can also be found at the cell surface of some tumor cells. Notably, membrane-bound HSP70 has been shown to elicit antitumor immunity $[26,27]$. Therefore, HSP70 and B220 expression was determined by flow cytometry on the plasma membrane of the T-cell lines treated with $\mathrm{As}_{2} \mathrm{O}_{3}$ for $24 \mathrm{~h}$ in doses ranging from 1 to $20 \mu \mathrm{M}$. HSP70 was not detected on untreated T-cell lines (Figure 3B). $\mathrm{As}_{2} \mathrm{O}_{3}$ treatment upregulated membranebound HSP70 in EL-4, BW5147, Jurkat and HPB-ALL cells in a dose-dependent manner. The expression pattern of HSP70 was parallel to that of B220, and HSP70 was expressed in $\mathrm{B}_{220^{+}}$cells only (Figure $3 \mathrm{~B}$ ). As observed for B220 expression, a significantly higher percentage of EL-4 cells, and to a lesser extent of Jurkat cells, than HPB-ALL cells expressed HSP70 (Figure 3B) (Table 1). L1210 cells, constitutively expressing B220, had a low level of expression of membrane-bound HSP70 (Additional file 2: Figure S2C) similar to HSP70 levels observed in HPB-ALL cells. Therefore, $\mathrm{As}_{2} \mathrm{O}_{3}$ treatment induced both HSP70 and B220 membrane expression and the levels of expression correlated with leukemic T-cell lines sensitivity to $\mathrm{As}_{2} \mathrm{O}_{3}$.

B220/CD45R expression on $\mathrm{As}_{2} \mathrm{O}_{3}$-treated leukemic $\mathrm{T}$ cells is not a direct consequence of T-cell activation unlike the expression induced by the calcium ionophore A23187

The induction of B220 on EL-4, BW5147, Jurkat and HPB-ALL leukemic T cells treated with $\mathrm{As}_{2} \mathrm{O}_{3}$ is suggestive of the induction observed on normal $\mathrm{T}$ cells entering apoptosis after repeated activation by their antigen. T-cell activation can be evidenced by measuring the expression of surface marker CD69 [28]. Therefore, we have analyzed the induction of CD69 on the T-cell lines treated with $\mathrm{As}_{2} \mathrm{O}_{3}$ as well as with PMA and calcium ionophore A23187 as positive controls. As expected, the activation of leukemic T cells with $10 \mathrm{ng} / \mathrm{ml}$ of PMA for $5 \mathrm{~h}$ induced a strong expression of the activation marker CD69 in cells within region $\mathrm{R} 2$ only, which encompasses living cells. In contrast, we did not detect the expression of CD69 by flow cytometry on the cell surface of $\mathrm{As}_{2} \mathrm{O}_{3}$-treated leukemic T cells, whatever the doses tested ( 1 to $20 \mu \mathrm{M}$, data not shown), suggesting that the induction of B220 expression by $\mathrm{As}_{2} \mathrm{O}_{3}$ is not a direct consequence of T-cell activation.

As observed with PMA, activation of the leukemic T-cell lines with $100 \mathrm{nM}$ to $800 \mathrm{nM}$ of the calcium ionophore A23187 for $24 \mathrm{~h}$ induced the expression of CD69 on EL-4, BW5147, L1210, and Jurkat cells and also, to a lesser extent, on HPB-ALL cells (Table 1). However, the number of $\mathrm{CD} 9^{+}$cells decreased with the dose of A23187, and hardly any $\mathrm{CD}^{+} 9^{+}$cells were detected at the higher dose of A23187 (data not shown). In contrast, a dose-dependent expression of B220 was detected on EL-4, BW5147, Jurkat and HPB-ALL cells, although significant differences were observed in the percentages of $\mathrm{B}^{2} 20^{+}$cells among T-cell lines (Figure 5). Thus, $50 \%$ of $\mathrm{B}^{2} 20^{+}$cells were detected at a dose of A23187 around $50 \mathrm{nM}$ for HPB-ALL cells, 100-130 nM for Jurkat cells, $275 \mathrm{nM}$ for BW5147 and $600 \mathrm{nM}$ for EL-4. cells (Figure 5, see B220 induction). Interestingly, at around the same dose of A23187 that induced B220 expression, 50\% of HPB-ALL, Jurkat, BW5147 and EL-4 cells died (Annexin V and PI staining, Figure 5, see Cell viability) or shifted from region $\mathrm{R} 2$ to $\mathrm{R} 1$ on the FSC $v s$. SSC dot plots (Figure 5, see Cell morphology). In contrast to $\mathrm{As}_{2} \mathrm{O}_{3}$, the constitutive expression of B220 on L1210 T cells renders these cells remarkably sensitive to A23187 (Figure 5, see Cell viability and Cell morphology). Therefore, B220 expression level strictly correlates with the susceptibility of $\mathrm{T}$ cells to die following A23187 activation, suggesting an interesting link between transmembrane phosphatase B220 expression and cell death. Moreover, in contrast with $\mathrm{As}_{2} \mathrm{O}_{3}$ treatment, membrane-bound HSP70 was not upregulated following treatment with calcium ionophore A23187, even on the $\mathrm{B} 220^{+}$T-cell subpopulations (data not shown).

\section{Relative contributions of apoptosis and necrosis in $\mathrm{T}$ leukemia cell death induction by $\mathrm{As}_{2} \mathrm{O}_{3}$ or calcium ionophore A23187}

It is widely considered that $\mathrm{As}_{2} \mathrm{O}_{3}$ exerts its cytotoxic activity by triggering cell apoptosis [12]. However, it has been reported that $\mathrm{As}_{2} \mathrm{O}_{3}$ can induce cell death independently of caspase activity [29,30]. We have determined whether the apoptotic and/or necrotic pathways were activated upon $\mathrm{As}_{2} \mathrm{O}_{3}$ or calcium ionophore A23187 treatment in EL-4, Jurkat, HPB-ALL and L1210 cells. Because BW5147 cells displayed similar sensitivity to $\mathrm{As}_{2} \mathrm{O}_{3}$ and $\mathrm{A} 23187$ as EL-4 and Jurkat cells, respectively, the latter two T-cell lines were preferentially chosen for subsequent experiments. In the presence of $\mathrm{As}_{2} \mathrm{O}_{3}$ or $\mathrm{A} 23187$, no $\mathrm{PI}^{+}$cells (either Annexin $\mathrm{V}^{-}$or Annexin $\mathrm{V}^{+}$) were detected in the B220-negative cell 


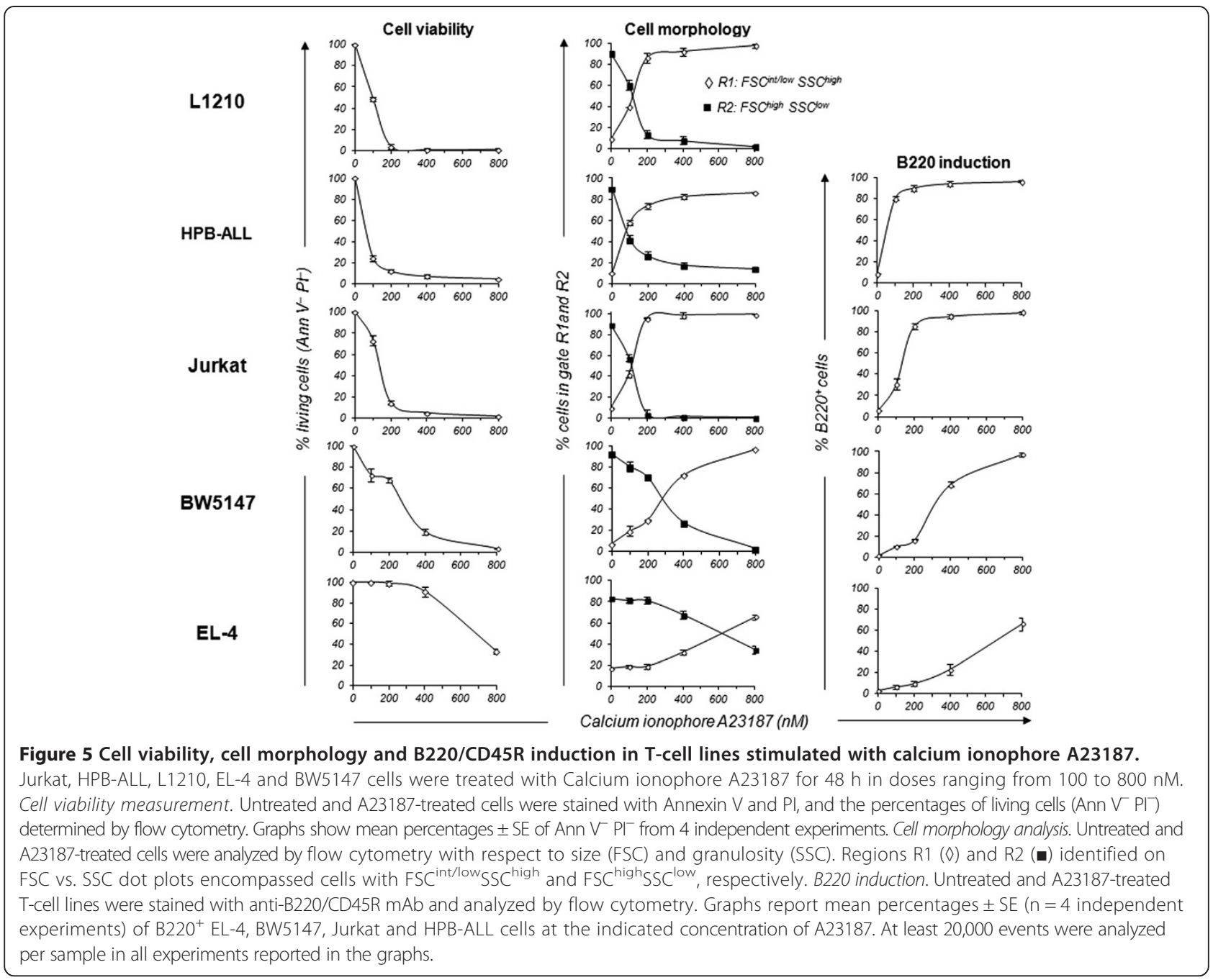

subpopulation (data not shown). In contrast, in the $\mathrm{B} 220^{+}$cell subpopulation, the $\mathrm{IC}_{50}$ value of $\mathrm{As}_{2} \mathrm{O}_{3}$ that causes either apoptotic or necrotic cell death was $1.5 \mu \mathrm{M}$ for EL-4 cells, $8 \mu \mathrm{M}$ for Jurkat cells and $9 \mu \mathrm{M}$ for L1210 cells. For $\mathrm{B} 220^{+} \mathrm{HPB}-\mathrm{ALL}$ cells, even at the higher dose of $20 \mu \mathrm{M} \mathrm{As} \mathrm{A}_{2} \mathrm{O}_{3}$, only $39 \pm 2.5 \%$ of the cells were killed (Figure 6A). Furthermore, to discriminate between late apoptosis $\left(\mathrm{PI}^{+} /\right.$Annexin $\left.\mathrm{V}^{+}\right)$and necrosis $\left(\mathrm{PI}^{+} /\right.$Annexin $\mathrm{V}^{-}$), we analyzed the levels of active initiator caspases 8 and 9 in the $\mathrm{B}_{2} 2 \mathrm{O}^{+} \mathrm{PI}^{+}$-cell subpopulation. Significative differences were observed between the T-cell lines, even though the levels of active caspase 8 and/or 9 increased with the dose of $\mathrm{As}_{2} \mathrm{O}_{3}$ (Figure 6B and C). Thus, $\mathrm{EC}_{50}$ for caspase 8 activation was $2 \mu \mathrm{M}$ for EL-4 cells and $6.5 \mu \mathrm{M}$ for Jurkat cells (Figure 6B). To activate caspase 9 in these T-cell lines, almost twice as much $\mathrm{As}_{2} \mathrm{O}_{3}$ was required compared with caspase 8 (Figure 6C). Even at the higher dose of $20 \mu \mathrm{M}$ $\mathrm{As}_{2} \mathrm{O}_{3}$, only 16 to $19 \%$ of HPB-ALL cells and $\sim 40 \%$ of L1210 cells contained active caspase 8 or caspase 9 (Figure 6B and $\mathrm{C}$ ). Since $\mathrm{As}_{2} \mathrm{O}_{3}$ can also induce cell death independently of caspase activity [30], we have determined the percentages of necrotic cells $\left(\mathrm{PI}^{+} /\right.$Annexin $^{-}$or $\mathrm{PI}^{+}$/active Caspase ${ }^{-}$). No necrotic cells were detected in $\mathrm{As}_{2} \mathrm{O}_{3}$-treated EL-4 cells. In contrast, 4 to $29 \%$ necrotic cells were detected in $\mathrm{As}_{2} \mathrm{O}_{3}$-treated Jurkat, HPB-ALL and L1210 cells (Figure 6D). In agreement with Figure 4, the $\mathrm{IC}_{50}$ value of calcium ionophore $\mathrm{A} 237187$ that cause either apoptotic or necrotic cell death was between $80 \mathrm{nM}$ and $150 \mathrm{nM}$ for L1210, HPB-ALL and Jurkat cells compared with around $600 \mathrm{nM}$ for EL-4 cells (Figure 6A). The relative contributions of apoptotic and necrotic cell death in calcium ionophore A23187 cytotoxicity showed an opposite pattern compared with $\mathrm{As}_{2} \mathrm{O}_{3}$ cytotoxicity. In the presence of calcium ionophore A23187, up to $32 \%$ necrotic cells were detected in EL-4 cells, whereas no necrotic cells were detected in HPB-ALL cells and less than $8 \%$ were detected in L1210 and Jurkat cell lines (Figure 6D). Moreover, EL-4 cells did not contain active caspase 8 and 9, whereas high levels of active caspase 8 and 9 were detected in L1210, HPB-ALL, and Jurkat T-cell lines (Figure 6B and C). 


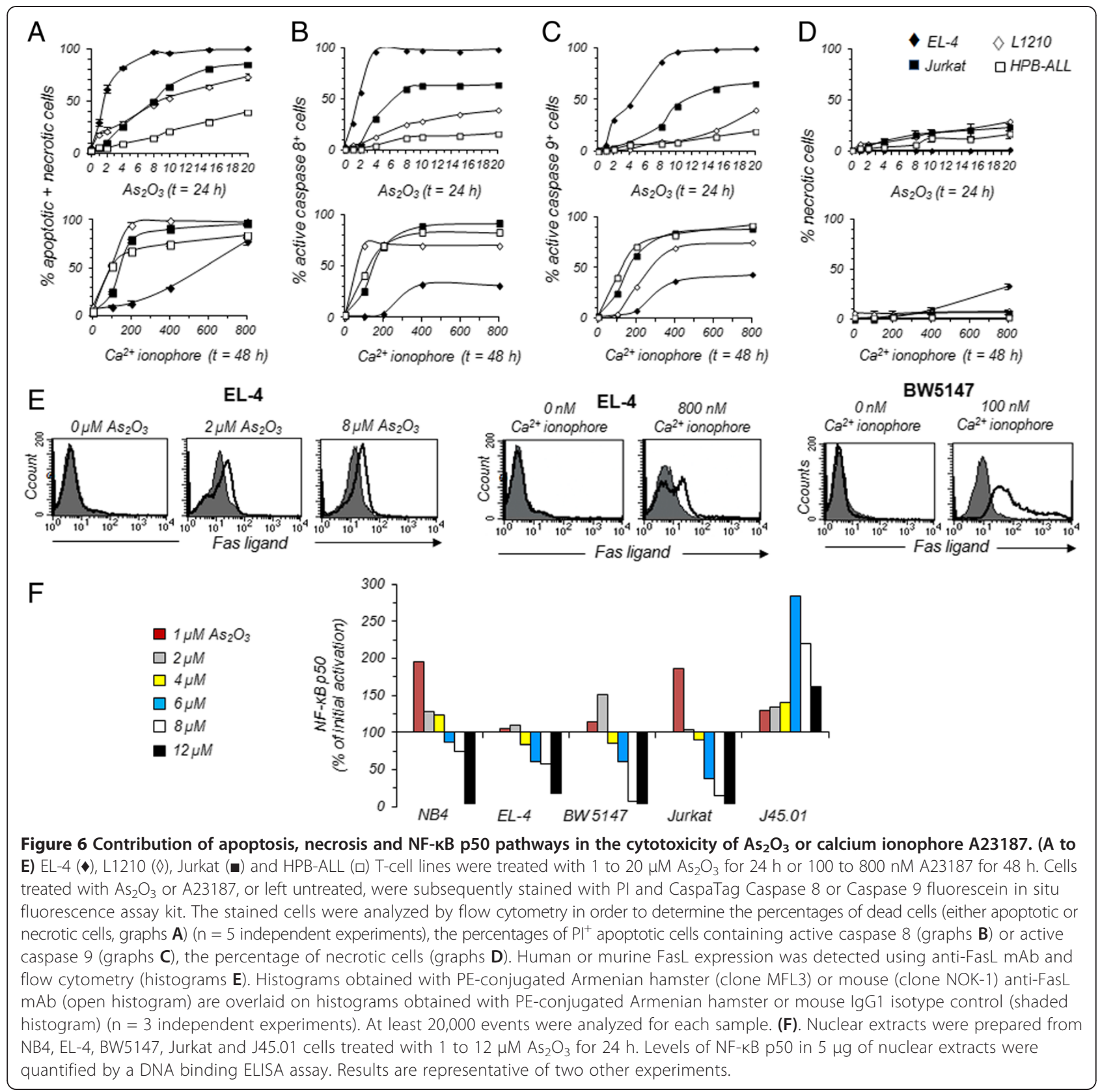

To summarize, when high levels of B220 membrane expression were achieved with low doses of $\mathrm{As}_{2} \mathrm{O}_{3}$ or calcium ionophore A23187, the leukemic T-cell lines died by apoptosis only. When high doses of $\mathrm{As}_{2} \mathrm{O}_{3}$ or calcium ionophore A23187 were required to induce B220 expression, the T-cell lines died by both apoptosis and necrosis. The constitutive expression of B220 on L1210 cells did not favor apoptosis or necrosis, and cells died by a combination of the two. Taken together, our data suggest that transmembrane tyrosine phosphatase B220 plays a checkpoint role in apoptotic pathways since its expression is markedly and rapidly induced on the surface of $\mathrm{T}$ cells undergoing apoptosis.

\section{Expression of Fas and Fas ligand upon treatment with} $\mathrm{As}_{2} \mathrm{O}_{3}$ or $\mathrm{A} 23187$

The presence of active initiator caspase 8 in the T-cell lines treated with $\mathrm{A} 23187$ or $\mathrm{As}_{2} \mathrm{O}_{3}$ suggested that cells entered apoptosis upon engagement of death receptors such as Fas. In normal T cells, Fas receptor is constitutively expressed whereas its ligand, FasL, is expressed after $\mathrm{T}$ cell activation. The five $\mathrm{T}$-cell lines were treated or not with $\mathrm{As}_{2} \mathrm{O}_{3}$ or calcium ionophore A23187 for $24 \mathrm{~h}$ and $48 \mathrm{~h}$, and the levels of Fas and FasL expression were determined by flow cytometry. Fas receptor is strongly expressed on untreated Jurkat cells, weakly expressed on untreated HPB-ALL cells, and not detected 
on untreated EL-4, BW5147 and L1210 cells. No significant modulation in Fas receptor expression was observed after treatment with $\mathrm{As}_{2} \mathrm{O}_{3}$ or $\mathrm{A} 23187$ (data not shown). Its ligand, FasL, is not expressed on untreated T-cell lines. Upon treatment with $2 \mu \mathrm{M} \mathrm{As} \mathrm{O}_{3}$ for $24 \mathrm{~h}$, only the highly $\mathrm{As}_{2} \mathrm{O}_{3}$-sensitive EL-4 T-cell line expressed FasL, with $100 \%$ of EL-4 cells being FasL positive although weakly (Figure 6E). FasL ${ }^{+}$EL-4 cells were equally detected in regions $\mathrm{R} 1$ and $\mathrm{R} 2$ (data not shown), suggesting that FasL is expressed before apoptosis. FasL-expressing BW5147, L1210, Jurkat and HPB-ALL cells were not detected even after $48 \mathrm{~h}$ of treatment with $\mathrm{As}_{2} \mathrm{O}_{3}$ (data not shown).

Treatment with the calcium ionophore A23187 upregulated FasL expression on EL-4, BW5147 and L1210 cells (Figure 6E and Additional file 2: Figure S2D), but not on Jurkat and HPB-ALL cells (data not shown). While $24 \mathrm{~h}$ of treatment were sufficient to induce FasL expression on BW5147 and EL-4 cells, $48 \mathrm{~h}$ were required to induce such expression on L1210 cells (Additional file 2: Figure S2D). However, the expression levels of FasL were significantly higher on BW5147 cells than on EL-4 and L1210 cells. In addition, FasL upregulation was achieved using a concentration of calcium ionophore A23187 around 4 and 8 times higher in EL-4 cells and L1210 cells, respectively, than in BW5147 cells. FasL-expressing EL-4, BW5147 and L1210 cells were equally detected in regions $\mathrm{R} 1$ and $\mathrm{R} 2$ (data not shown). The expression of FasL on EL-4 cells treated with $\mathrm{As}_{2} \mathrm{O}_{3}$ or A23187, and on BW5147 and L1210 cells only when treated with A23187, strongly suggest that $\mathrm{As}_{2} \mathrm{O}_{3}$ and A23187 trigger FasL expression through different signaling pathways. Furthermore, the absence of either Fas or FasL, or both, on $\mathrm{A}_{2} \mathrm{O}_{3}$ - or A23187-treated cells indicates that their activation of caspase 8 is independent of the Fas/FasL pathway and must depend on other death pathway.

\section{$\mathrm{As}_{2} \mathrm{O}_{3}$ treatment represses nuclear translocation of NF-кB p50}

NF- $\kappa \mathrm{B}$ activity regulates the apoptosis of various cancer cell lines. Activation of NF- $\mathrm{kB}$ can promote or prevent apoptosis, depending on the stimuli utilized and the cell type [31]. Conflicting results have been published on the activation status of $\mathrm{NF}-\mathrm{kB}$ in $\mathrm{As}_{2} \mathrm{O}_{3}$-treated leukemia $\mathrm{T}$ cells. One report has shown that $\mathrm{As}_{2} \mathrm{O}_{3}$ treatment markedly decreases constitutive NF- $\mathrm{kB}$ activation [32]. In another study, the authors could not detect any decrease in the translocation of the p65 subunit of NF-kB [33]. This discrepancy may be due to differences in the doses of $\mathrm{As}_{2} \mathrm{O}_{3}$ used to treat leukemic $\mathrm{T}$ cells. Therefore, we have quantified NF- $\mathrm{BB}$ p50 in nuclear extracts from NB4, EL-4, BW5147, Jurkat (clone E6-1) and CD45deficient variant (clone J45.01) treated with a large range of doses (i.e. $1 \mu \mathrm{M}$ to $12 \mu \mathrm{M}$ ). We found that $\mathrm{As}_{2} \mathrm{O}_{3}$ treatment represses nuclear translocation of NF- $\mathrm{KB}$ p50 in $\mathrm{As}_{2} \mathrm{O}_{3}$-treated $\mathrm{T}$ cells in a dose-dependent manner (Figure 6F). Importantly, nuclear translocation of NF- $\mathrm{kB}$ p50 was strongly increased in the CD45-deficient Jurkat T-cell line (clone J45.01) treated with $\mathrm{As}_{2} \mathrm{O}_{3}$ compared to wild-type Jurkat cells (Figure 6F). Thus, after a treatment with $6 \mu \mathrm{M} \mathrm{As} \mathrm{O}_{3}$ ( $\mathrm{IC}_{50}$ value for the cytotoxic effect of $\mathrm{As}_{2} \mathrm{O}_{3}$ on Jurkat cells) J45.01 cells contained markedly more nuclear NF-kB p50 (about 3 times more) than wild-type Jurkat cells, suggesting a link between $\mathrm{B} 220$ and NF-kB signaling pathways.

\section{Discussion}

In APL-derived NB4 cells, $\mathrm{As}_{2} \mathrm{O}_{3}$ triggers apoptosis at concentrations of 0.5 to $2 \mu \mathrm{M}$ [8]. The cytotoxic properties of $\mathrm{As}_{2} \mathrm{O}_{3}$ are not restricted to $\mathrm{APL}$, and $\mathrm{As}_{2} \mathrm{O}_{3}$ induces apoptosis in various types of hematopoietic and solid tumors [12]. However, hematologic tumor cells vary considerably in their sensitivity to $\mathrm{As}_{2} \mathrm{O}_{3}$. To gain insight into the mechanisms underlying the $\mathrm{As}_{2} \mathrm{O}_{3}$ sensitivity of malignant $\mathrm{T}$ cells, we firstly selected two human (Jurkat and HPB-ALL) and three murine (EL-4, BW5147 and L1210) T-cell lines for their marked differences in sensitivity to $\mathrm{As}_{2} \mathrm{O}_{3}$ cytotoxicity over a large range of doses (i.e. $1 \mu \mathrm{M}$ to $20 \mu \mathrm{M}$ ). Thus, $50 \%$ of EL-4 cells are killed at a clinically relevant concentration of about 1-2 $\mu \mathrm{M} \mathrm{As} \mathrm{As}_{2} \mathrm{O}_{3}$, whereas concentrations of $\sim 2.5 \mu \mathrm{M}$ $\mathrm{As}_{2} \mathrm{O}_{3}$ for BW5147, $\sim 6 \mu \mathrm{M} \mathrm{As} \mathrm{O}_{3}$ for Jurkat and $\sim 12-$ $15 \mu \mathrm{M} \mathrm{As} \mathrm{A}_{2} \mathrm{O}_{3}$ for L1210 and HPB-ALL T-cell lines are required to kill approximately $50 \%$ of the cells. Using this tumor panel, we have shown that: 1) differences in the intracellular levels of $\mathrm{GSH}$ and $\mathrm{O}_{2}{ }^{-}$are not sufficient to account for their differences in $\mathrm{As}_{2} \mathrm{O}_{3}$ sensitivity; 2) transmembrane tyrosine phosphatase B220 is induced on EL-4, BW5147, Jurkat and HPB-ALL T-cell lines, but not APLderived NB4 cells, upon treatment with $\mathrm{As}_{2} \mathrm{O}_{3}$ in a dose and time dependent manner; 3) the degree of B220 induction on the T-cell lines is strongly correlated with the sensitivity to $\mathrm{As}_{2} \mathrm{O}_{3}$ cytotoxicity; 4) surprisingly, B220 is constitutively expressed on the L1210 T-cell line; 5) membrane-bound HSP70, known to induce antitumor immunity, is upregulated by $\mathrm{As}_{2} \mathrm{O}_{3}$ in parallel with B220 induction; 6) initiator caspases 8 and 9 are activated by $\mathrm{As}_{2} \mathrm{O}_{3}$ in the $\mathrm{T}$-cell lines where this activation parallels B220 induction, but not in L1210 cells; 7) $\mathrm{As}_{2} \mathrm{O}_{3}$ represses nuclear translocation of NF- $\mathrm{KB}$ p50 in a dose dependent manner; 8) FasL upregulation by $\mathrm{As}_{2} \mathrm{O}_{3}$ is found on Fas-negative EL-4 cells only, indicating that caspase 8 activation is most probably independent of the Fas/FasL pathway [34]. However, the absence of FasL on some T-cell lines (either human or murine) might be due to the rapid shedding of FasL by protease activities induced by $\mathrm{As}_{2} \mathrm{O}_{3}$ or calcium ionophore 
A23187, as we have reported for TNF- $\alpha$ and CD62L upon treatment with Ionomycin or ATP [35].

Contradictory data have been published on the efficacy of $\mathrm{As}_{2} \mathrm{O}_{3}$ treatment against tumors belonging to the lymphoid lineages. Evidence for a pro-apoptotic effect of $\mathrm{As}_{2} \mathrm{O}_{3}$ against human malignant T- and B-cell lines [36], cutaneous T-cell lymphoma [37] or HTLV-I-associated adult T-cell leukemia [38] was provided by in vitro studies. However, it has been shown, in a multi-institution phase II study, that $\mathrm{As}_{2} \mathrm{O}_{3}$ exhibits limited efficacy against lymphoid malignancies, even though the patients received ascorbic acid in addition to $\mathrm{As}_{2} \mathrm{O}_{3}$ [39]. The authors of this clinical study expected that agents such as ascorbic acid, which depletes intracellular GSH, could potentiate arsenic-induced apoptosis, since it has been described previously [10] that the sensitivity of cells to $\mathrm{As}_{2} \mathrm{O}_{3}$ are inversely correlated with their intracellular GSH content. $\mathrm{As}_{2} \mathrm{O}_{3}$ interacts with sulfhydryl ( $\mathrm{SH}$ ) groups of biologically active molecules. The binding of $\mathrm{As}_{2} \mathrm{O}_{3}$ to the $\mathrm{SH}$ group of GSH could cause a drastic decrease in the capacity to scavenge ROS in cells with a low basal GSH content, resulting in overproduction of intracellular ROS that could trigger cell apoptosis. However, our present study shows that EL-4 and BW5147 T-cell lines, which were the most sensitive to $\mathrm{As}_{2} \mathrm{O}_{3}$-induced cytotoxicity among the cells lines studied $\left(\mathrm{IC}_{50}\right.$ of approximately 1 to $2.5 \mu \mathrm{M})$ had the highest baseline GSH content (Figure 2). Likewise, L1210 and HPB-ALL T cells that were significantly more resistant to $\mathrm{As}_{2} \mathrm{O}_{3}$ cytotoxicity ( $\mathrm{IC}_{50}$ of approximately 12 to $15 \mu \mathrm{M}$ ) had significantly lower baseline GSH content than EL-4 and BW5147 cells (Figure 2). In the presence of $\mathrm{As}_{2} \mathrm{O}_{3}$, intracellular GSH content was differently modulated in the T-cell lines, but without any correlation with their $\mathrm{As}_{2} \mathrm{O}_{3}$ sensitivity. Thus, GSH level in the highly sensitive NB4 cell line was unaffected by the dose of $1 \mu \mathrm{M} \mathrm{As} \mathrm{O}_{2} \mathrm{O}_{3}$, whereas it was markedly decreased in the BW5147 T-cell line and also, although to a lesser extent, in the resistant Jurkat cells (Figure 2). Because intracellular GSH content did not appear to be a key factor in determining $\mathrm{As}_{2} \mathrm{O}_{3}$ sensitivity of these five leukemia T-cell lines, we further explored the evolution of $\mathrm{O}_{2}^{-}$production upon treatment with $\mathrm{As}_{2} \mathrm{O}_{3}$. The five $\mathrm{T}$-cell lines showed a great heterogeneity in levels of intrinsic $\mathrm{O}_{2}^{-}$production (Figure 2), which, interestingly, were 2 to 8 times higher than in APL-derived NB4 cells. As expected, the levels of $\mathrm{O}_{2}^{-}$were significantly increased in APL-derived NB4 cells in the presence of $\mathrm{As}_{2} \mathrm{O}_{3}$. In T-cell lines, the situation was more complex. While the levels of $\mathrm{O}_{2}^{-}$increased significantly, in Jurkat, L1210, and to a lesser extent HPB-ALL T cells treated with $\mathrm{As}_{2} \mathrm{O}_{3}$, they remained unchanged in EL-4 and BW5147 T cells. Therefore, the changes of $\mathrm{O}_{2}{ }^{-}$production upon treatment with $\mathrm{As}_{2} \mathrm{O}_{3}$ are not correlated with the differences in $\mathrm{As}_{2} \mathrm{O}_{3}$ sensitivity that we observed among the five T-cell lines. In contrast to other tumor cells [5], neither the intracellular GSH content nor the production of $\mathrm{O}_{2}{ }^{-}$had any decisive effect on $\mathrm{As}_{2} \mathrm{O}_{3}-$ induced apoptosis of the five $\mathrm{T}$-cell lines studied. Therefore, our findings suggest that the depletion of leukemic $\mathrm{T}$ cells in their intracellular GSH content by ascorbic or butyric acid are not necessarily relevant to potentiate the cytotoxic effect of $\mathrm{As}_{2} \mathrm{O}_{3}$. Furthermore, it has been reported that the expression level of aquaglyceroporin (AQP)9, a transmembrane protein that controls arsenic transport, correlated positively with $\mathrm{As}_{2} \mathrm{O}_{3}$-induced cytotoxicity in myeloid and lymphoid leukemia cell lines [40]. In contrast, the overexpression of AQP9 in melanoma cells significantly increased the resistance to arsenite-induced apoptosis [41]. These reports prompted us to determine the levels of AQP9 mRNA by semi-quantitative RT-PCR in EL-4, BW5147, L1210, Jurkat and HPB-ALL T-cell lines, and in APLderived NB4 cells. However, we did not find any correlation between the expression levels of AQP9 mRNA and the $\mathrm{As}_{2} \mathrm{O}_{3}$ sensitivity in the T-cell lines (unpublished data). Therefore, our data strongly suggest the existence of additional factors determining the sensitivity of $\mathrm{T}$ cells to $\mathrm{As}_{2} \mathrm{O}_{3}$ cytotoxicity. Herein, we have hypothesized that phosphatase B220 could be such a factor, since we have shown previously that treatment with $\mathrm{As}_{2} \mathrm{O}_{3}$ of autoimmune MRL/lpr mice selectively eliminates pathogenic B220-expressing T cells in vivo [13,14].

Normal effector $\mathrm{T}$ cells entering apoptosis after repeated activation by their antigen express the tyrosine phosphatase B220 on their surface $[15,16,42]$, suggesting a role for B220 induction in the transition from activation to apoptosis. On the other hand, B220 is the isoform of CD45 predominantly expressed on pathogenic $\mathrm{DN} T$ cells from patients and mice with a deficiency in the death receptor Fas, or its ligand FasL. FasL-deficient mice ( $g l d$ mutation) with only one functional CD45 allele ( $\mathrm{gld} / \mathrm{gld}, \mathrm{CD} 45+/-)$ display a strong reduction in the pathogenic DN T-cell population [43], suggesting that CD45 is an important regulator of T-cell apoptosis or a survival factor for $\mathrm{T}$ cells. Whether and how B220 expression on T cells regulates signaling for death or survival remains unknown. The induction of B220 and FasL (in EL-4 cells) as well as the activation of initiator caspase-8 in $\mathrm{As}_{2} \mathrm{O}_{3}$-treated leukemic T-cell lines were reminiscent of apoptosis in normal effector $\mathrm{T}$ cells triggered by repeated antigenic stimulation. Therefore, leukemic T-cell lines were activated with calcium ionophore A23187, a well-known trigger for T-cell activation and death. Importantly, we found that $\mathrm{As}_{2} \mathrm{O}_{3}$ and calcium ionophore A23187 have opposite efficiencies on the T-cell lines, evidenced by the induction of B220, activation marker CD69 and membrane-bound HSP70 expression, and cell death (data summarized in Table 1). While both 
B220 expression and cell death were massively induced in EL-4 cells after treatment with $\mathrm{As}_{2} \mathrm{O}_{3}$, they were only slightly induced after treatment with calcium ionophore A23187. The complete reverse situation was observed in HPB-ALL cells, indicating that $\mathrm{A} 23187$ and $\mathrm{As}_{2} \mathrm{O}_{3}$ had opposite effects on B220 expression and cell death on the same leukemic T-cell panel. Moreover, treatment with A23187, but not $\mathrm{As}_{2} \mathrm{O}_{3}$, induced the activation marker CD69 on T-cell lines before B220 expression and cell death, indicating that $\mathrm{A} 23187$, but not $\mathrm{As}_{2} \mathrm{O}_{3}$, kills the $\mathrm{T}$-cell lines by an activation-induced cell death mechanism.

HSP70 is overexpressed in various cancer cells [44]. HSP70 inhibits apoptosis by modulating multiple events within apoptotic pathways, which might promote cancer development $[45,46]$. However, a tumor-specific plasma membrane form of HSP70 has been described [44,47], which facilitates tumor rejection by the immune system [27,47-49]. In the present study, we found a strong upregulation of membrane-bound $\mathrm{HSP70}$ by $\mathrm{As}_{2} \mathrm{O}_{3}$ treatment, but not by the calcium ionophore A23187. This upregulation of $\mathrm{HSP70}$ by $\mathrm{As}_{2} \mathrm{O}_{3}$ strictly paralleled the induction of B220 on EL-4, BW5147, Jurkat and HPB-ALL T-cell lines (Table 1). Consequently, $\mathrm{As}_{2} \mathrm{O}_{3}$ sensitive EL-4 cells expressed both high levels of HSP70 and B220, whereas low expression levels of HSP70 and B220 were found on $\mathrm{As}_{2} \mathrm{O}_{3}$-resistant HPB-ALL cells. Likewise, constitutive expression of $\mathrm{B} 220$ on $\mathrm{As}_{2} \mathrm{O}_{3}$ resistant L1210 cells was associated with low expression levels of membrane-bound HSP70. In vivo, the direct cytotoxic effects of $\mathrm{As}_{2} \mathrm{O}_{3}$ could be amplified by the upregulation of membrane-bound HSP70 on tumor cells, which might facilitate tumor immune rejection.

CD45 is known to positively regulate antigen-receptor signaling during activation of normal $\mathrm{T}$ and $\mathrm{B}$ cells via dephosphorylation of src kinases, and to negatively regulate cytokine receptor signaling via dephosphorylation of JAK kinases $[17,18]$. In this study, we show that the modulation of B220 cell surface expression plays an important role in determining the sensitivity of leukemic $\mathrm{T}$ cells to $\mathrm{As}_{2} \mathrm{O}_{3}$ and calcium ionophore A23187 cytotoxicity. In addition, we found that $\mathrm{As}_{2} \mathrm{O}_{3}$ treatment represses nuclear translocation of NF- $\mathrm{kB}$ p50 in a dose dependent manner. Moreover nuclear translocation of NF- $\mathrm{kB}$ p50 was increased in CD45-deficient Jurkat $\mathrm{T}$ cell line (clone J45.01) after treatment with $\mathrm{As}_{2} \mathrm{O}_{3}$, suggesting a link between B220 and NF-kB signaling pathways.

In conclusion, on a panel of mouse and human leukemic T-cell lines, we have presented evidence for a tight correlation between the induction of B220 membrane expression and their sensitivity to cell death induced by $\mathrm{As}_{2} \mathrm{O}_{3}$ or $\mathrm{A} 23187$. Our data strongly support the hypothesis that B220 plays a checkpoint role in death pathways. This could provide additional tools to potentiate $\mathrm{As}_{2} \mathrm{O}_{3}$ therapy against leukemic T cells.

\section{Conclusions}

In contrast to $\mathrm{As}_{2} \mathrm{O}_{3}$-treated APL cells, GSH content and $\mathrm{O}_{2}{ }^{-}$production do not play a significant role in $\mathrm{As}_{2} \mathrm{O}_{3}$ sensitivity of leukemic $\mathrm{T}$ cells, suggesting the existence of additional factors determining the sensitivity of $\mathrm{T}$ cells to $\mathrm{As}_{2} \mathrm{O}_{3}$ cytotoxicity. The $\mathrm{B} 220$ isoform of transmembrane tyrosine phosphatase $\mathrm{CD} 45$ may be one such factor. Indeed, we show that $\mathrm{As}_{2} \mathrm{O}_{3}$ treatment induces B220 plasma membrane expression and cell death in leukemic T-cell lines in a dose and time dependent manner. The levels of B220 induction on the T-cell lines strictly correlate with both the extent and form of cell death. Leukemic T cells died by an apoptotic form of cell death when high levels of B220 membrane expression were achieved with low doses of $\mathrm{As}_{2} \mathrm{O}_{3}$. Taken together, our data suggest that transmembrane tyrosine phosphatase B220 plays a checkpoint role in apoptotic pathways since its expression is markedly and rapidly induced on the surface of $\mathrm{T}$ cells undergoing apoptosis.

\section{Materials and methods Reagents}

Arsenic trioxide $\left(\mathrm{As}_{2} \mathrm{O}_{3}\right)$, phorbol 12-myristate 13-acetate (PMA) and 4',6-diamidino-2-phenylindole (DAPI) were purchased from Sigma-Aldrich (St. Louis, MO), and Calcium ionophore A23187 was from Calbiochem (EMD Biosciences Inc, San Diego, CA). $\mathrm{As}_{2} \mathrm{O}_{3}$ was dissolved in $1 \mathrm{M} \mathrm{NaOH}$, and stored as a $330 \mathrm{mM}$ stock solution, which was further diluted to $5 \mathrm{mM}$ with phosphate-buffered saline (PBS).

\section{Cell culture and cell treatment}

Leukemic cell lines used in this study included mouse T-cell lines EL-4, BW5147 and L1210, human T-cell lines HPB-ALL, Jurkat (clone E6-1) and CD45 deficient variant of the E6-1 clone of Jurkat (clone J45.01) (European Collection of Cell Cultures), and human acute promyelocytic leukemia cell line NB4. Leukemic T cell lines (EL-4, BW5147, L1210, Jurkat (clone E6-1), HPB-ALL), and APL derived cell line NB4 were kindly provided by Dr Colette Kanellopoulos-Langevin (Centre for Inflammation Research, INSERM, Hôpital Bichat, Paris, France) and Dr Jacqueline Robert-Lézénès (Inserm U940, Hôpital Saint-Louis, Paris, France), respectively. All cells were grown in RPMI 1640 containing Glutamax (Invitrogen, Cergy Pontoise, France) and supplemented with 10\% heat-inactivated fetal calf serum, $50 \mathrm{U} / \mathrm{ml}$ penicillin and $50 \mu \mathrm{g} / \mathrm{ml}$ streptomycin at $37^{\circ} \mathrm{C}$ in a humidified $5 \%$ $\mathrm{CO}_{2}$ atmosphere. This culture medium will be referred to as complete medium. To avoid possible effects of cell density on cell growth and survival, cells were maintained at less than $5 \times 10^{5}$ cells $/ \mathrm{ml}$ with daily adjusting cell density through the addition of fresh 
medium. Cell viability was estimated by the $4 \%$ Trypanblue dye exclusion assay.

Leukemic $\mathrm{T}$ cells were seeded in 12-well plates at a density of $1 \times 10^{5}$ cells $/ \mathrm{ml}$ and incubated in complete medium alone or in the presence of different concentrations of $\mathrm{As}_{2} \mathrm{O}_{3}$ or calcium ionophore $\mathrm{A} 23187$ at $37^{\circ} \mathrm{C}$ for 12,24 and $48 \mathrm{~h}$ depending on the experiment.

\section{Flow cytometry and imaging flow cytometry}

The expression levels of cell surface markers on untreated and $\mathrm{As}_{2} \mathrm{O}_{3}$ - or A23187-treated leukemic T-cell lines was analyzed by flow cytometry using either fluorescein isothiocyanate (FITC)-, phycoerythrin (PE)-, allophycocyanin (APC)- or biotin-conjugated monoclonal antibodies (mAb): rat anti-mouse Thy-1.2/CD90.2 (clone 53-2.1), anti-CD45 (clone 2D1), anti-B220/CD45R (clone RA3-6B2), anti-mouse and human CD69 (clone H1.2 F3 and FN50), anti-mouse and human Fas (clone Jo2 and DX2), anti-mouse and human FasL (clone MFL3 and NOK-1) and anti-HSP70 (clone SMC-103A) (all from eBioscience, CliniSciences, Montrouge, France), and rat IgG2a, mouse IgG, mouse IgG1, and Armenian hamster IgG1 as the isotype control (eBiosciences). Use of mAb to mouse and human $\mathrm{Fc} \gamma$ receptor (PharMingen, BD Bioscience, San Jose, CA) avoided non-specific antibody binding.

The subcellular localization of B220/CD45R molecules was determined by imaging flow cytometry, following the protocol supplied by the manufacturer (Amnis Corp., Seattle, WA). Briefly, cells $\left(1 \times 10^{6}\right)$ stained with PE-conjugated antiB220/CD45R mAbs and DAPI were run on an ImageStream apparatus (ImagoSeine, Institut Jacques Monod, CNRSUniversité Paris Diderot, France). At least 10,000 images were collected per sample at $40 \times$ or $60 \times$ magnification, and analyzed using IDEAS image-analysis software (Amnis Corp.).

\section{Cell proliferation, cell death and caspase activation assay} Total cell numbers in untreated and $\mathrm{As}_{2} \mathrm{O}_{3}$-treated groups were determined by flow cytometry by acquiring events for a fixed time period of $1 \mathrm{~min} . \mathrm{As}_{2} \mathrm{O}_{3}$ - and Calcium ionophore-induced cell death was analyzed by propidium iodide (PI) (Invitrogen) staining, and flow cytometry. Among $\mathrm{PI}^{+}$cells, to discriminate between apoptotic and necrotic cells, the cells were stained using either FITCconjugated Annexin V (PharMingen) or CaspaTag Caspase 8 or Caspase 9 In situ Assay Kit, Fluorescein according to the manufacturer's instructions (Chemicon, Temecula, CA). Annexin V staining and the levels of active caspase-8 and caspase- 9 were measured by flow cytometry.

Analysis of reduced glutathione content and $\mathrm{O}_{2}{ }^{-}$production GSH content and $\mathrm{O}_{2}{ }^{-}$production in T-cell lines treated or not with $\mathrm{As}_{2} \mathrm{O}_{3}$ were measured by flow cytometry using $100 \mathrm{nM}$ CellTracker probe CMFDA and $5 \mu \mathrm{M}$ DHE probes, respectively, following the manufacturer's instructions (Molecular Probes, Eugene, OR).

\section{B220/CD45R mRNA quantification by RT-PCR}

Total RNA was extracted from $5 \times 10^{6}$ leukemic T cells treated or not with $\mathrm{As}_{2} \mathrm{O}_{3}$ using the RNeasy Plus Mini kit (Qiagen, Courtaboeuf, France) following the manufacturer's instructions and was used to generate cDNA utilizing oligo(dT) primer and SuperScript II Reverse Transcriptase (Invitrogen). PCR were conducted for 25 cycles with the following primer pairs: B220/CD45R forward primer (5'-CAC ATA TCA TCC AGG TGT GTT ATC C-3') and reverse primer (5'-GTC CTC TCC CCT GGC ACA CCT G-3'); $\beta$-actin forward primer (5'-ATC GTG GGC CGC CCT AGG CAC-3') and reverse primer (5'-TGG CCT TAG GGT TCA GAG GGG C-3'). Semi-quantitative determination (ImageJ densitometric analysis software program) of B220 cDNA, present in each of the various samples, was normalized with respect to the concentration of internal control cDNA ( $\beta$-actin) detected in the same sample, and B220/ $\beta$-actin cDNA ratios were calculated.

\section{Quantitative measurement of NF-KB activation}

Nuclear extracts were prepared from $8 \times 10^{6}$ leukemic $\mathrm{T}$ cells treated or not with $\mathrm{As}_{2} \mathrm{O}_{3}$. The protein from nuclear extracts was quantified by the Bradford method (Bio-Rad, France). An equal amount of nuclear extract $(5 \mu \mathrm{g})$ was assayed for NF-KB p50 activity using a TransAm NFkB p50 Transcription Factor Assay Kit according to the manufacturer's recommendations (ActiveMotif, Rixensart, Belgium).

\section{Statistical analyses}

Data are reported as fluorescence means \pm SE. Significant differences between sample means were determined using the Student $t$ test. Statistical significance was accepted at $P \leq 0.05$.

\section{Additional files}

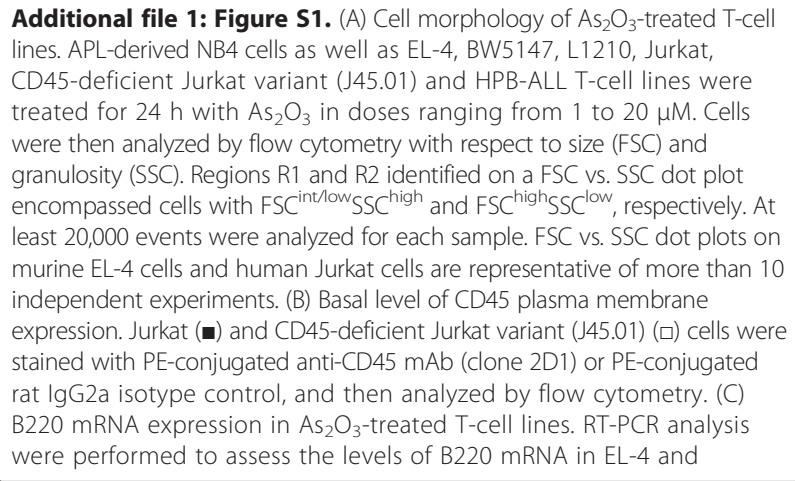

Additional file 1: Figure S1. (A) Cell morphology of $\mathrm{As}_{2} \mathrm{O}_{3}$-treated T-cell lines. APL-derived NB4 cells as well as EL-4, BW5147, L1210, Jurkat, CD45-deficient Jurkat variant (J45.01) and HPB-ALL T-cell lines were treated for $24 \mathrm{~h}$ with $\mathrm{As}_{2} \mathrm{O}_{3}$ in doses ranging from 1 to $20 \mu \mathrm{M}$. Cells were then analyzed by flow cytometry with respect to size (FSC) and granulosity (SSC). Regions R1 and R2 identified on a FSC vs. SSC dot plot encompassed cells with FSC int/lowsSChigh and $\mathrm{FSC}^{\text {high }} \mathrm{SSC}^{\text {low }}$, respectively. At least 20,000 events were analyzed for each sample. FSC vs. SSC dot plots on murine EL-4 cells and human Jurkat cells are representative of more than 10 independent experiments. (B) Basal level of CD45 plasma membrane expression. Jurkat (घ) and CD45-deficient Jurkat variant (J45.01) ( $\square$ ) cells were stained with PE-conjugated anti-CD45 mAb (clone 2D1) or PE-conjugated rat lgG2a isotype control, and then analyzed by flow cytometry. (C) B220 mRNA expression in $\mathrm{As}_{2} \mathrm{O}_{3}$-treated T-cell lines. RT-PCR analysis were performed to assess the levels of B220 mRNA in EL-4 and 
BW5147 T cells cultured in the presence or absence of 1, 2 and $4 \mu \mathrm{M}$ $\mathrm{As}_{2} \mathrm{O}_{3}$ for 3,6 and $9 \mathrm{~h}$. Results are representative of two other experiments,

Additional file 2: Figure S2. (A) Constitutive B220/CD45R cell surface expression on $\mathrm{CD} 0^{+} \mathrm{L} 1210 \mathrm{~T}$ cells. Cells were labeled with APC-conjugated anti-CD90 and PE-conjugated anti-B220/CD45R mAbs, or fluorescent isotype control, and then analyzed by flow cytometry. (B) B220 expression on $\mathrm{As}_{2} \mathrm{O}_{3}$-treated cells. $\mathrm{L} 1210 \mathrm{~T}$ cells were treated without or with $\mathrm{As}_{2} \mathrm{O}_{3}$ for $24 \mathrm{~h}$ in doses ranging from 1 to $20 \mu \mathrm{M}$. L1210 cells were then stained with $\mathrm{PE}$-conjugated anti-B220/CD45R mAb or PE-conjugated rat lgG2a isotype control, and further analyzed by flow cytometry with respect to size (FSC) versus granulosity (SSC) and B220 expression. FSC vs. SSC dot plots were used to define gates R1 and R2 with FSC ${ }^{\text {intlow }}$ SSC high and FSC high $S S C^{\text {low }}$, respectively. $B 220$ histograms were then gated in $R 1$ and $R 2$ to determine the percentages of cells expressing B220 ( $n=10$ independent experiments). At least 20,000 events were analyzed for each sample. (C) HSP70 induction on $\mathrm{As}_{2} \mathrm{O}_{3}$-treated cells. $\mathrm{L} 1210 \mathrm{~T}$ cells stained with anti-B220 and anti-HSP70 antibodies were analyzed by flow cytometry as described in Figure 3B. (D) FasL induction on $\mathrm{Ca}^{2+}$ ionophore treated cells. Histograms obtained with PE-conjugated Armenian hamster (clone MFL3) anti-FasL $\mathrm{mAb}$ (open histogram) are overlaid on histograms obtained with PEconjugated Armenian hamster isotype control (shaded histogram) $(n=3$ independent experiments). At least 20,000 events were analyzed for each sample.

Additional file 3: Figure S3. Duration of B220/CD45R membrane expression upon $\mathrm{As}_{2} \mathrm{O}_{3}$ treatment. EL-4 and Jurkat T cells were cultured in the absence or in the presence of $1,2,4$ or $8 \mu \mathrm{M} \mathrm{As} \mathrm{O}_{3}$ for $24 \mathrm{~h}$. Then, cells were extensively washed with PBS to eliminate all traces of $\mathrm{As}_{2} \mathrm{O}_{3}$, and cultured for 9 additional days. Expression of $\mathrm{B} 220$ was measured by flow cytometry at the time of $\mathrm{As}_{2} \mathrm{O}_{3}$ removal (referred to as day 0 ) and 1 to 9 days after $\mathrm{As}_{2} \mathrm{O}_{3}$ was removed. At least 20,000 events were analyzed for each sample. Dot plots of FSC vs. SSC on $8 \mu_{M} \mathrm{As}_{2} \mathrm{O}_{3}$-treated EL-4 and Jurkat cells are representative of more than 3 independent experiments. Graphs report the percentages of $\mathrm{B}_{2} 20^{+} \mathrm{EL}-4$ or $\mathrm{B} 220^{+}$Jurkat cells at the indicated time-points and concentrations of $\mathrm{As}_{2} \mathrm{O}_{3}$, with the same isotype control labelling as in Figure 3.

\section{Abbreviations}

APL: Acute promyelocytic leukemia; AQP9: Aquaglyceroporin-9; $\mathrm{As}_{2} \mathrm{O}_{3}$ : Arsenic trioxide; DN: Double negative; FasL: Fas ligand; FSC: Forward scatter; $\mathrm{EC}_{50}$ : Half maximal effective concentration; $\mathrm{IC}_{50}$ : Half maximal inhibitory concentration; HSP70: Heat shock protein-70; mAb: Monoclonal antibody; NF-kB: Nuclear factor-kappa B; PI: Propidium iodide; ROS: Reactive oxygen species; GSH: Reduced glutathione; SSC: Side scatter; $\mathrm{O}_{2}^{-}$: Superoxide anion radical; MFI: Mean fluorescence intensity.

\section{Competing interests}

The authors declare they have no competing interests.

\section{Authors' contributions}

$\mathrm{PB}$ and $\mathrm{MB}$ conceived and designed the experiments; $\mathrm{MB}$ and $\mathrm{AM}$ performed the experiments; $M B, A M$ and $P B$ analyzed the data; $P B$ wrote the manuscript. All authors read and approved the final manuscript.

\section{Acknowledgments}

We thank Dr Colette Kanellopoulos-Langevin (Centre for Inflammation Research, INSERM U699, Hôpital Bichat, Paris, France) for helpful discussions and for critical review of the manuscript. This work was funded by the Centre National de la Recherche Scientifique (CNRS), and grants from Agence Nationale de la Recherche (ANR-07BLAN0089-02).

\section{Author details}

IInstitut Jacques Monod, CNRS, Université Paris Diderot, Paris, France. 2INSERM U1012, Université Paris-Sud, Le Kremlin Bicêtre, Orsay, France. ${ }^{3}$ INSERM U757, Université Paris-Sud, Orsay, France.

Received: 16 January 2014 Accepted: 6 November 2014 Published: 19 November 2014

\section{References}

1. Shen ZX, Chen GQ, Ni JH, Li XS, Xiong SM, Qiu QY, Zhu J, Tang W, Sun GL, Yang KQ, Chen Y, Zhou L, Fang ZW, Wang YT, Ma J, Zhang P, Zhang TD, Chen SJ, Chen Z, Wang ZY: Use of arsenic trioxide (As2O3) in the treatment of acute promyelocytic leukemia (APL): II. Clinical efficacy and pharmacokinetics in relapsed patients. Blood 1997, 89:3354-3360.

2. Soignet SL, Maslak P, Wang ZG, Jhanwar S, Calleja E, Dardashti LJ, Corso D, DeBlasio A, Gabrilove J, Scheinberg DA, Pandolfi PP, Warrell RP Jr: Complete remission after treatment of acute promyelocytic leukemia with arsenic trioxide. N Engl J Med 1998, 339:1341-1348.

3. Niu C, Yan H, Yu T, Sun HP, Liu JX, Li XS, Wu W, Zhang FQ, Chen Y, Zhou L, Li JM, Zeng XY, Yang RR, Yuan MM, Ren MY, Gu FY, Cao Q, Gu BW, Su XY, Chen GQ, Xiong SM, Zhang TD, Waxman S, Wang ZY, Chen Z, Hu J, Shen ZX, Chen SJ: Studies on treatment of acute promyelocytic leukemia with arsenic trioxide: remission induction, follow-up, and molecular monitoring in 11 newly diagnosed and 47 relapsed acute promyelocytic leukemia patients. Blood 1999, 94:3315-3324.

4. Lallemand-Breitenbach V, Zhu J, Chen Z, de The H: Curing APL through PML/RARA degradation by As2O3. Trends Mol Med 2012, 18:36-42.

5. Miller WH Jr, Schipper HM, Lee JS, Singer J, Waxman S: Mechanisms of action of arsenic trioxide. Cancer Res 2002, 62:3893-3903.

6. Lallemand-Breitenbach V, Jeanne M, Benhenda S, Nasr R, Lei M, Peres L, Zhou J, Zhu J, Raught B, de The H: Arsenic degrades PML or PML-RARalpha through a SUMO-triggered RNF4/ubiquitin-mediated pathway. Nat Cell Bio/ 2008, 10:547-555.

7. Tatham MH, Geoffroy MC, Shen L, Plechanovova A, Hattersley N, Jaffray EG, Palvimo JJ, Hay RT: RNF4 is a poly-SUMO-specific E3 ubiquitin ligase required for arsenic-induced PML degradation. Nat Cell Biol 2008, 10:538-546.

8. Chen GQ, Shi XG, Tang W, Xiong SM, Zhu J, Cai X, Han ZG, Ni JH, Shi GY, Jia PM, Liu MM, He KL, Niu C, Ma J, Zhang P, Zhang TD, Paul P, Naoe T, Kitamura K, Miller W, Waxman S, Wang ZY, de The H, Chen SJ, Chen Z: Use of arsenic trioxide (As2O3) in the treatment of acute promyelocytic leukemia (APL): I. As203 exerts dose-dependent dual effects on APL cells. Blood 1997, 89:3345-3353.

9. Yang $\mathrm{CH}$, Kuo ML, Chen JC, Chen YC: Arsenic trioxide sensitivity is associated with low level of glutathione in cancer cells. Br J Cancer 1999, 81:796-799.

10. Dai J, Weinberg RS, Waxman S, Jing Y: Malignant cells can be sensitized to undergo growth inhibition and apoptosis by arsenic trioxide through modulation of the glutathione redox system. Blood 1999, 93:268-277.

11. Chou WC, Jie C, Kenedy AA, Jones RJ, Trush MA, Dang CV: Role of NADPH oxidase in arsenic-induced reactive oxygen species formation and cytotoxicity in myeloid leukemia cells. Proc Natl Acad Sci U S A 2004, 101:4578-4583.

12. Dilda PJ, Hogg PJ: Arsenical-based cancer drugs. Cancer Treat Rev 2007, 33:542-564.

13. Bobé $P$, Bonardelle D, Benihoud K, Opolon P, Chelbi-Alix MK: Arsenic trioxide: a promising novel therapeutic agent for lymphoproliferative and autoimmune syndromes in MRL/lpr mice. Blood 2006, 108:3967-3975.

14. Le Gall SM, Legrand J, Benbijja M, Safya H, Benihoud K, Kanellopoulos JM, Bobé P: Loss of P2X7 receptor plasma membrane expression and function in pathogenic B220+ double-negative T lymphocytes of autoimmune MRL/Ipr mice. PLoS One 2012, 7:e52161.

15. Renno T, Attinger A, Rimoldi D, Hahne M, Tschopp J, MacDonald HR: Expression of B220 on activated T cell blasts precedes apoptosis. Eur J Immunol 1998, 28:540-547.

16. Bleesing JJ, Morrow MR, Uzel G, Fleisher TA: Human T cell activation induces the expression of a novel CD45 isoform that is analogous to murine B220 and is associated with altered O-glycan synthesis and onset of apoptosis. Cell Immunol 2001, 213:72-81.

17. Hermiston $M L, X u Z$, Weiss $A: C D 45$ : a critical regulator of signaling thresholds in immune cells. Annu Rev Immunol 2003, 21:107-137.

18. Holmes N: CD45: all is not yet crystal clear. Immunology 2006, 117:145-155.

19. Rhee I, Veillette A: Protein tyrosine phosphatases in lymphocyte activation and autoimmunity. Nat Immunol 2012, 13:439-447.

20. Klaus SJ, Sidorenko SP, Clark EA: CD45 ligation induces programmed cell death in T and B lymphocytes. J Immunol 1996, 156:2743-2753.

21. Stillman BN, Hsu DK, Pang M, Brewer CF, Johnson P, Liu FT, Baum LG: Galectin-3 and galectin-1 bind distinct cell surface glycoprotein receptors to induce T cell death. J Immunol 2006, 176:778-789. 
22. Clark MC, Baum LG: T cells modulate glycans on CD43 and CD45 during development and activation, signal regulation, and survival. Ann N Y Acad Sci 2012, 1253:58-67.

23. Davison K, Mann KK, Waxman S, Miller WH Jr: JNK activation is a mediator of arsenic trioxide-induced apoptosis in acute promyelocytic leukemia cells. Blood 2004, 103:3496-3502.

24. Pelicano H, Feng L, Zhou Y, Carew JS, Hileman EO, Plunkett W, Keating MJ, Huang P: Inhibition of mitochondrial respiration: a novel strategy to enhance drug-induced apoptosis in human leukemia cells by a reactive oxygen species-mediated mechanism. J Biol Chem 2003, 278:37832-37839.

25. Pelicano H, Carney D, Huang P: ROS stress in cancer cells and therapeutic implications. Drug Resist Updat 2004, 7:97-110.

26. Multhoff G, Botzler C, Wiesnet M, Muller E, Meier T, Wilmanns W, Issels RD: A stress-inducible 72-kDa heat-shock protein (HSP72) is expressed on the surface of human tumor cells, but not on normal cells. Int J Cancer 1995 61:272-279.

27. Stangl S, Gehrmann M, Riegger J, Kuhs K, Riederer I, Sievert W, Hube K, Mocikat R, Dressel R, Kremmer E, Pockley AG, Friedrich L, Vigh L, Skerra A, Multhoff G: Targeting membrane heat-shock protein 70 (Hsp70) on tumors by cmHsp70.1 antibody. Proc Natl Acad Sci U S A 2011, 108:733-738.

28. Sancho D, Gomez M, Sanchez-Madrid F: CD69 is an immunoregulatory molecule induced following activation. Trends Immunol 2005, 26:136-140.

29. McCafferty-Grad J, Bahlis NJ, Krett N, Aguilar TM, Reis I, Lee KP, Boise LH: Arsenic trioxide uses caspase-dependent and caspase-independent death pathways in myeloma cells. Mol Cancer Ther 2003, 2:1155-1164.

30. Scholz C, Wieder T, Starck L, Essmann F, Schulze-Osthoff K, Dorken B, Daniel PT: Arsenic trioxide triggers a regulated form of caspase-independent necrotic cell death via the mitochondrial death pathway. Oncogene 2005, 24:1904-1913.

31. Perkins ND: The diverse and complex roles of NF-kappaB subunits in cancer. Nat Rev Cancer 2012, 12:121-132.

32. El-Sabban ME, Nasr R, Dbaibo G, Hermine O, Abboushi N, Quignon F, Ameisen JC, Bex F, de The H, Bazarbachi A: Arsenic-interferon-alpha-triggered apoptosis in HTLV-I transformed cells is associated with tax down-regulation and reversal of NF-kappa B activation. Blood 2000, 96:2849-2855.

33. Bornhauser BC, Bonapace L, Lindholm D, Martinez R, Cario G, Schrappe M, Niggli FK, Schafer BW, Bourquin JP: Low-dose arsenic trioxide sensitizes glucocorticoid-resistant acute lymphoblastic leukemia cells to dexamethasone via an Akt-dependent pathway. Blood 2007, 110:2084-2091.

34. Tenev T, Bianchi K, Darding M, Broemer M, Langlais C, Wallberg F, Zachariou A, Lopez J, MacFarlane M, Cain K, Meier P: The Ripoptosome, a signaling platform that assembles in response to genotoxic stress and loss of IAPs. Mol Cell 2011, 43:432-448.

35. Le Gall SM, Bobé P, Reiss K, Horiuchi K, Niu XD, Lundell D, Gibb DR, Conrad D, Saftig $P$, Blobel CP: ADAMs 10 and 17 represent differentially regulated components of a general shedding machinery for membrane proteins such as transforming growth factor alpha, L-Selectin, and tumor necrosis factor alpha. Mol Biol Cell 2009, 20:1785-1794.

36. Zhu $X H$, Shen $Y L$, Jing $Y K$, Cai $X$, Jia PM, Huang $Y$, Tang $W$, Shi GY, Sun $Y P$, Dai J, Wang ZY, Chen SJ, Zhang TD, Waxman S, Chen Z, Chen GQ: Apoptosis and growth inhibition in malignant lymphocytes after treatment with arsenic trioxide at clinically achievable concentrations. J Natl Cancer Inst 1999, 91:772-778.

37. Michel L, Dupuy A, Jean-Louis F, Sors A, Poupon J, Viguier M, Musette P, Dubertret L, Degos L, Dombret $H$, Bachelez $H$ : Arsenic trioxide induces apoptosis of cutaneous $T$ cell lymphoma cells: evidence for a partially caspase-independent pathway and potentiation by ascorbic acid (vitamin C). J Invest Dermatol 2003, 121:881-893.

38. Bazarbachi A, El-Sabban ME, Nasr R, Quignon F, Awaraji C, Kersual J, Dianoux L, Zermati $Y$, Haidar $\mathrm{JH}$, Hermine $\mathrm{O}$, de The H: Arsenic trioxide and interferon-alpha synergize to induce cell cycle arrest and apoptosis in human T-cell lymphotropic virus type I-transformed cells. Blood 1999, 93:278-283.

39. Chang J, Voorhees P, Kolesar J, Ahuja H, Sanchez F, Rodriguez G, Kim K, Werndli J, Bailey H, Kahl B: Phase II study of arsenic trioxide and ascorbic acid for relapsed or refractory lymphoid malignancies: a Wisconsin Oncology Network study. Hematol Oncol 2009, 27:11-16.

40. Leung J, Pang A, Yuen WH, Kwong YL, Tse EW: Relationship of expression of aquaglyceroporin 9 with arsenic uptake and sensitivity in leukemia cells. Blood 2007, 109:740-746.
41. Gao L, Gao Y, Li X, Howell P, Kumar R, Su X, Vlassov AV, Piazza GA, Riker Al, Sun $D, X i Y$ : Aquaporins mediate the chemoresistance of human melanoma cells to arsenite. Mol Oncol 2012, 6:81-87.

42. Renno T, Hahne M, Tschopp J, MacDonald HR: Peripheral T cells undergoing superantigen-induced apoptosis in vivo express B220 and upregulate Fas and Fas ligand. J Exp Med 1996, 183:431-437.

43. Brooks WP, Lynes MA: Effects of hemizygous CD45 expression in the autoimmune Fasl(gld/gld) syndrome. Cell Immunol 2001, 212:24-34.

44. Sherman M, Multhoff G: Heat shock proteins in cancer. Ann N Y Acad Sci 2007, 1113:192-201.

45. Takayama S, Reed JC, Homma S: Heat-shock proteins as regulators of apoptosis. Oncogene 2003, 22:9041-9047.

46. Beere HM: "The stress of dying": the role of heat shock proteins in the regulation of apoptosis. J Cell Sci 2004, 117:2641-2651.

47. Gastpar R, Gehrmann M, Bausero MA, Asea A, Gross C, Schroeder JA, Multhoff $G$ : Heat shock protein 70 surface-positive tumor exosomes stimulate migratory and cytolytic activity of natural killer cells. Cancer Res 2005, 65:5238-5247.

48. Suto $R$, Srivastava PK: A mechanism for the specific immunogenicity of heat shock protein-chaperoned peptides. Science 1995, 269:1585-1588.

49. Asea A, Kraeft SK, Kurt-Jones EA, Stevenson MA, Chen LB, Finberg RW, Koo GC, Calderwood SK: HSP70 stimulates cytokine production through a CD14-dependant pathway, demonstrating its dual role as a chaperone and cytokine. Nat Med 2000, 6:435-442.

doi:10.1186/1476-4598-13-251

Cite this article as: Benbijja et al: Sensitivity of leukemic T-cell lines to arsenic trioxide cytotoxicity is dependent on the induction of phosphatase B220/CD45R expression at the cell surface. Molecular Cancer 2014 13:251.

\section{Submit your next manuscript to BioMed Central and take full advantage of:}

- Convenient online submission

- Thorough peer review

- No space constraints or color figure charges

- Immediate publication on acceptance

- Inclusion in PubMed, CAS, Scopus and Google Scholar

- Research which is freely available for redistribution 